\title{
Subsoils-a sink for excess fertilizer $P$ but a minor contribution to P plant nutrition: evidence from long-term fertilization trials
}

\author{
Nina Siebers ${ }^{1 *} \mathbb{C}$, Liming Wang ${ }^{1}$, Theresa Funk' ${ }^{1}$, Sabine von Tucher ${ }^{2}$, Ines Merbach ${ }^{3}$, Kathlin Schweitzer ${ }^{4}$ and \\ Jens Kruse $e^{1,5}$
}

\begin{abstract}
Background: The phosphorus (P) stocks of arable subsoils not only influence crop production but also fertilizer $\mathrm{P}$ sequestration. However, the extent of this influence is largely unknown. This study aimed to (i) determine the extent of $P$ sequestration with soil depth, (ii) analyze $P$ speciation after long-term $P$ fertilization, and (iii) compare soil $P$ tests in predicting crop yields. We analyzed four long-term fertilizer trials in Germany to a depth of $90 \mathrm{~cm}$. Treatments received either mineral or organic $\mathrm{P}$, or a combination of both, for 16 to 113 years. We determined inorganic and organic $\mathrm{P}$ pools using sequential extraction, and $\mathrm{P}$ speciation using ${ }^{31} \mathrm{P}$ nuclear magnetic resonance (NMR) and X-ray absorption near edge structure (XANES) spectroscopy. In addition, we applied three P soil tests, double-lactate (DL), calcium acetate lactate (CAL), and diffusive gradients in thin films (DGT).

Results: The results suggested that plants are capable of mobilizing $P$ from deeper soil layers when there is a negative $\mathrm{P}$ budget of the topsoil. However, fertilization mostly only showed insignificant effects on $\mathrm{P}$ pools, which were most pronounced in the topsoil, with a 1.6- to 4.4-fold increase in labile inorganic $\mathrm{P}\left(\mathrm{P}_{\mathrm{i}}\right.$; resin- $\left.\mathrm{P}, \mathrm{NaHCO}_{3}-\mathrm{P}_{\mathrm{i}}\right)$ after mineral fertilization and a 0 - to 1.9-fold increase of organic $\mathrm{P}\left(\mathrm{P}_{0} ; \mathrm{NaHCO}_{3}-\mathrm{P}_{\mathrm{o}}, \mathrm{NaOH}-\mathrm{P}_{\mathrm{o}}\right)$ after organic $\mathrm{P}$ fertilization. The differences in $\mathrm{P}_{\mathrm{o}}$ and $\mathrm{P}_{\mathrm{i}}$ speciation were mainly controlled by site-specific factors, e.g., soil properties or soil management practice rather than by fertilization. When modeling crop yield response using the Mitscherlich equation, we obtained the highest $R^{2}\left(R^{2}=0.61, P<0.001\right)$ among the soil $P$ tests when using topsoil $P_{\mathrm{DGT}}$. However, the fit became less pronounced when incorporating the subsoil.
\end{abstract}

Conclusion: We conclude that if the soil has a good $\mathrm{P}$ supply, the majority of $\mathrm{P}$ taken up by plants originates from the topsoil and that the DGT method is a mechanistic surrogate of P plant uptake. Thus, DGT is a basis for optimization of $P$ fertilizer recommendation to add as much $P$ fertilizer as required to sustain crop yields but as low as necessary to prevent harmful $P$ leaching of excess fertilizer $P$.

Keywords: Bad Lauchstädt, Freising Dürnast, Dahlem, XANES spectroscopy, DGT, ${ }^{31}$ P NMR

\section{Background}

Phosphorus (P) is indispensable for plant growth and one of the essential nutrient elements for agriculture. Despite being present in soils in large quantities, not only in

\footnotetext{
*Correspondence: n.siebers@fz-juelich.de

${ }^{1}$ Institute of Bio- and Geosciences-Agrosphere (IBG-3),

Forschungszentrum Jülich, 52425 Jülich, Germany

Full list of author information is available at the end of the article
}

topsoils but also in the subsoil, most $\mathrm{P}$ is not readily available chemically to plants [33, 49], often making P fertilization essential to maintaining high crop yields. However, there are uncertainties regarding finite $P$ rock reserves [26], discussions about an uneven distribution of deposits [8], and environmental concerns such as the eutrophication of water bodies due to surplus $\mathrm{P}$ application [61].
Springer Open

(c) The Author(s) 2021. This article is licensed under a Creative Commons Attribution 4.0 International License, which permits use, sharing, adaptation, distribution and reproduction in any medium or format, as long as you give appropriate credit to the original author(s) and the source, provide a link to the Creative Commons licence, and indicate if changes were made. The images or other third party material in this article are included in the article's Creative Commons licence, unless indicated otherwise in a credit line to the material. If material is not included in the article's Creative Commons licence and your intended use is not permitted by statutory regulation or exceeds the permitted use, you will need to obtain permission directly from the copyright holder. To view a copy of this licence, visit http://creativeco mmons.org/licenses/by/4.0/. 
Thus, there is a need for a more sufficient (not more than required) and efficient (higher yields per applied P) use of $\mathrm{P}$ in the future. This includes, for example, the recycling of $\mathrm{P}$ from waste and residues, as well as increasing utilization of existing $\mathrm{P}$ in the soil through optimal fertilization and plant management.

The subsoil (here defined as soil underneath the plough layer, approximately $>30 \mathrm{~cm}$ ) can serve as a P reservoir for plant nutrition, as it can store substantial amounts of $\mathrm{P}$ ranging from 25 to $70 \%$ of total $\mathrm{P}$ in the soil profile [6, $7,29,32$ ]. Indeed, $10 \%$ to $50 \%$ of subsoil $P$ is acquired by crops when topsoil P is low [35]. However, to be readily available for plant nutrition, the $\mathrm{P}$ must be in a suitable chemical form and physically accessible to plants. Koch et al. [32] found that subsoil $P$ species in an agriculturally used Stagnic Cambisol were dominated by $\mathrm{P}$ associated with iron $(\mathrm{Fe})$ and aluminum (Al), irrespective of fertilizer treatment. In a subsequent study, they estimated how much of these subsoil P species contribute to plant nutrition and found that up to $30 \%$ of the plant $P$ requirements were covered by these P species under optimal soil physical conditions in the early plant growth phase [31]. The subsoil not only provides $\mathrm{P}$ to the plant, it also serves as a sink for excess fertilizer $P$ above plant requirements. The degree of P saturation (DPS) is an indicator for the risk of $\mathrm{P}$ losses. Soils with DPS values ranging from 25 to $40 \%$ have a high risk of $P$ loss, either by surface runoff or by leaching [48]. Thus, to optimize P fertilization and crop management, detailed knowledge about availability and accessibility is essential not only for topsoil but also for subsoil P resources.

In particular, the use of agricultural waste and residues for P fertilization, such as compost, manure, or green manure, is of importance for an efficient and sustainable closed-loop production system. Long-term field experiments are most suitable for examining $P$ fertilization management on the soil P status. They enable us to study complex fertilizer turnover processes in soil operating on different time scales and thus provide an overview of the effectiveness of fertilizer management on nutrient mobilization, transformation, translocation, and uptake [22, $30,76,79]$.

To obtain a detailed overview of the soil $\mathrm{P}$ status and the dynamics of topsoil and subsoils, the application of complementary methods is essential. A combination of wet-chemical extractions and spectroscopic approaches to determine P pools and their speciation has seen widespread application in agriculturally used soils under different fertilization management $[9,22,32,34,70]$. A promising method to determine labile $\mathrm{P}$ is the diffusive gradients in thin films (DGT) technique [18, 33]. The DGT approach mimics the actions of the plant roots in accessing available $\mathrm{P}$ at the soil-solution interface. This is achieved through a local decrease in the P concentration of the soil solution via sorption to an infinite iron-based $\mathrm{P}$ sink. It thus simultaneously triggers the resupply of $\mathrm{P}$ by diffusion from the bulk solution and desorption from the solid soil phase. A ${ }^{33} \mathrm{P}$ isotope dilution study showed that among eight agricultural soil $\mathrm{P}$ tests, $\mathrm{P}$ concentrations estimated by DGT exhibited the closest relation to the P uptake by plant roots [59]. This test is independent of the soil $\mathrm{pH}$ or calcium carbonate content [40], which may influence the erratic results of other extractionbased tests, such as double-lactate (DL) or calcium acetate lactate (CAL) [77]. Besides, if $\mathrm{P}$ is the only limiting nutrient element and if $P$ uptake is diffusion-driven, DGT appears to accurately determine yield response to $P$ fertilization $[41,47,62]$. Therefore, we assume that the DGT approach is more accurate in estimating crop yields than liquid chemical extraction-based procedures.

The DGT approach, in combination with sequential $\mathrm{P}$ fractionation methods [27], provides a detailed overview of P pools with different availabilities. However, as these methods are operationally defined, no precise information is obtained about the chemical $\mathrm{P}$ speciation in the soil. This can be overcome using spectroscopic approaches. Commonly applied spectroscopic approaches here are $\mathrm{P} K$-edge $\mathrm{X}$-ray absorption near edge structure (XANES) spectroscopy as well as ${ }^{31} \mathrm{P}$ liquid nuclear magnetic resonance ( ${ }^{31} \mathrm{P}$ NMR) spectroscopy. P XANES spectroscopy is an element-specific and non-invasive direct $\mathrm{P}$ speciation method that is mainly sensitive to the speciation of inorganic $P\left(P_{i}\right)$ species $[9$, 32, 33]. However, ${ }^{31} \mathrm{P}$ NMR enables the identification and speciation of organic $\mathrm{P}\left(\mathrm{P}_{\mathrm{o}}\right)$ forms $[11,12,33,67]$. Thus, a combination of these wet chemical and spectroscopic techniques provides a comprehensive overview of the availability and chemical form of $\mathrm{P}$ in soils.

There are numerous studies on the effect of different $P$ fertilizers on $P$ forms in the soil $[9,20,32,36,38]$. However, to the best of our knowledge, none of these studies comprises a broad spectrum of $\mathrm{P}$ fertilizer treatments together with analyses of the subsoil of different soil types. Here, we included three long-term field experiments that exhibit different soils, analyzed the topsoil and subsoils, and applied a multi-method approach including wet-chemical and spectroscopic approaches. This helps to provide an all-encompassing picture about how the effects of fertilization, soil type, and management on $\mathrm{P}$ pools are also relevant for crop yield prediction. To the best of our knowledge, this approach has never been applied to such an extent. With this study, we aim (i) to assess $P$ availability and speciation in soils after long-term application at different soil depths and (ii) to evaluate the suitability of the DGT approach in predicting crop yields compared to other soil P tests. We studied 
four long-term field experiments with different durations of $\mathrm{P}$ fertilizer management, ranging from 16 up to 113 years up to the time of sampling at three sites. All experimental sites had the same $\mathrm{P}$ fertilizer treatments, namely no $\mathrm{P}$ addition, mineral $\mathrm{P}$ addition, organic $\mathrm{P}$ addition in the form of compost, green manure or farmyard manure, and a combined mineral and organic treatment. We sampled all treatments down to a depth of $90 \mathrm{~cm}$. Topsoil and subsoil samples were subjected to a combination of DGT P analysis, sequential fractionation, P $K$-edge XANES spectroscopy, and ${ }^{31} \mathrm{P}$ NMR spectroscopy to demonstrate the long-term effects of fertilizer P management on $P$ pools and species.

\section{Materials and methods}

\section{Experimental sites and soil sampling}

We collected soil samples from four different agricultural long-term experimental sites for basic characteristics, sequential $\mathrm{P}$ fractionation, $\mathrm{P}_{\mathrm{DGT}}$ analyses, P XANES spectroscopy, and ${ }^{31} \mathrm{P}$ NMR spectroscopy. However, the agricultural long-term experimental site at the University of Rostock was analyzed for $\mathrm{P}_{\mathrm{DGT}}$ only, since data on sequential $\mathrm{P}$ fractionation, ${ }^{31} \mathrm{P}$ XANES, and NMR spectroscopy were previously published by Koch et al. [32]. Details on every experimental site can be found in Additional file 1: Table S1. The Dahlem and Bad Lauchstädt sites both received farmyard manure with substantial inorganic P contents [22]. However, to make a distinction from $\mathrm{P}$ applied by mineral fertilizers, the farmyard manure treatments are abbreviated as "organic P" or "mineral+organic P" (for a combined farmyard manure and mineral fertilizer treatment) throughout the manuscript.

Three soil cores were taken with a mechanical soil auger (diameter $3 \mathrm{~cm}$ ) randomly distributed over each plot down to a depth of $90 \mathrm{~cm}$. The soil cores obtained from Dahlem were divided into four segments, representing depths of $0-30 \mathrm{~cm}, 30-50 \mathrm{~cm}, 50-70 \mathrm{~cm}$, and $70-90 \mathrm{~cm}$, respectively, and slightly adjusted to horizons if required. The soil profiles were as follows: $\mathrm{Ap}(0-30 \mathrm{~cm}$ depth), EBw (30-50 cm depth), BtE (50-70 cm depth), and Bt (70-90 cm depth). The soil cores from Dürnast Freising and Bad Lauchstädt were divided into three segments, representing depths of $0-30 \mathrm{~cm}, 30-60 \mathrm{~cm}$, and $60-90 \mathrm{~cm}$, respectively. As no field replicates were available in Bad Lauchstädt, three soil cores from one plot were analyzed separately. The Chernozem soil at the Bad Lauchstädt sampling site has a very thick A horizon of about $50-60 \mathrm{~cm} \mathrm{[3].} \mathrm{The} \mathrm{soil} \mathrm{profile} \mathrm{was} \mathrm{as} \mathrm{follows:}$ former Ap (0-30 cm depth), Ah (30-45 cm), Ck+Ahk (45-60 cm), Ck $(60-90 \mathrm{~cm})$. We combined the Ahk and $\mathrm{Ck}+$ Ahk horizons and defined them as an unplowed $\mathrm{A}$ horizon. To enable direct comparisons among all three field experiments, we define the upper plowed $0-30 \mathrm{~cm}$ layer as topsoil and the unplowed $30-60 \mathrm{~cm}$ layer as well as the deepest layer $(60-90 \mathrm{~cm})$ as subsoil. For Dahlem and Freising Dürnast, soil core segments from each plot were well-mixed on-site and sub-sampled for the present study. All samples were air-dried and ground to pass through a 2-mm sieve.

\section{General soil analyses}

The soil texture was determined according to DIN ISO $11,277(<63 \mu \mathrm{m}$ to $2 \mu \mathrm{m}$ silt, $<2 \mu \mathrm{m}$ clay). Soil $\mathrm{pH}$ $\left(0.01 \mathrm{M} \mathrm{CaCl}_{2}\right)$ was measured according to Altermann et al. [3]. Soil carbon (C) and nitrogen $(\mathrm{N})$ analyses were performed using the dry combustion method followed by thermal conductivity detection of the released trace gases (vario MICRO cube, Elementar, Hanau, Germany). Total elemental concentrations of $\mathrm{P}$ from bulk soil $\left(\mathrm{P}_{\text {tot }}\right)$, iron $\left(\mathrm{Fe}_{\text {tot }}\right)$, aluminum $\left(\mathrm{Al}_{\text {tot }}\right)$, manganese $\left(\mathrm{Mn}_{\mathrm{tot}}\right)$, magnesium $\left(\mathrm{Mg}_{\text {tot }}\right)$, potassium $\left(\mathrm{K}_{\mathrm{tot}}\right)$, calcium $\left(\mathrm{Ca}_{\mathrm{tot}}\right)$, and sodium $\left(\mathrm{Na}_{\text {tot }}\right)$ were determined after the microwaveassisted digestion of $150 \mathrm{mg}$ with $0.7 \mathrm{~mL} \mathrm{HNO}_{3}$ and $2 \mathrm{~mL} \mathrm{HCl}$ using an inductively coupled plasma-optical emission spectrometer (ICP-OES; Thermo Fisher iCAP ${ }^{\mathrm{TM}}$ 7600). The bulk densities of the samples were calculated for each depth using the soil dry weights after drying at $105{ }^{\circ} \mathrm{C}$ and the auger volume at specific sampling depths. Total elemental stocks were calculated for each sampling depth with a respective bulk density (Additional file 1 : Table S1). In addition, ammonium oxalate extractable $\mathrm{P}$ $\left(\mathrm{P}_{\mathrm{OX}}\right)$, $\mathrm{Fe}\left(\mathrm{Fe}_{\mathrm{OX}}\right)$, and $\mathrm{Al}\left(\mathrm{Al}_{\mathrm{OX}}\right)$ were determined according to Schwertmann [58], DL extractable P was determined according to Riehm [53, 71], and CAL extractable $\mathrm{P}$ was determined according to Schüller [57, 72]. The total $\mathrm{P}$ concentrations in the extracts were determined by ICP-OES. Using the $\mathrm{P}_{\mathrm{OX}}, \mathrm{Fe}_{\mathrm{OX}}$, and $\mathrm{Al}_{\mathrm{OX}}$, the DPS was calculated as described in Koch et al. [32]. (Additional file 1: Fig. S1; see Additional file 1 for DPS results). All chemicals used for general soil analyses at least had the purity level for analysis.

\section{Soil analyses for $\mathrm{P}$ pools}

To test the desorptive P release from soils, we used the DGT approach described in the literature $[18,78]$. The DGT sampler (DGT Research Ltd, Lancaster, UK) consisted of a hydrogel layer containing an ion resin that is covered by a diffusion layer and protected by a membrane. It is a solute sampling technique, which can be applied to bulk soil estimations of the plant-available P $[41,59,65]$. We deployed the DGT device to the soil brought to $100 \%$ water holding capacity for $24 \mathrm{~h}$ at $21^{\circ} \mathrm{C}$. After deployment, the DGT units were dismantled and the ferrihydrite gel eluted in $1 \mathrm{~mL}$ of $1 \mathrm{M} \mathrm{HCl}$ solution for at least $24 \mathrm{~h}$. The concentration of total $\mathrm{P}$ in the eluent 
was measured by ICP-OES. Standard DGT formulae described by Zhang et al. [78] were used to calculate the $\mathrm{P}_{\mathrm{DGT}}$ concentrations.

All soil samples were also subjected to sequential $\mathrm{P}$ fractionation as described in [32]. In total, $0.5 \mathrm{~g}$ of the soil sample was sequentially extracted using (1) $\mathrm{H}_{2} \mathrm{O}+$ resin, (2) $0.5 \mathrm{M} \mathrm{NaHCO}_{3}$, (3) $0.1 \mathrm{M} \mathrm{NaOH}$, and (4) $1 \mathrm{M} \mathrm{H}_{2} \mathrm{SO}_{4}$ following the decreasing extractability of $\mathrm{P}$. The molybdate-reactive $\mathrm{P}$ [hereafter referred to as inorganic $\mathrm{P}\left(\mathrm{P}_{\mathrm{i}}\right)$ ] concentration of the filtrates was determined photometrically using the molybdenum blue method [46]. Total $\mathrm{P}$ was determined by ICP-OES and molybdate unreactive $\mathrm{P}$, principally organically complexed $\mathrm{P}$ [63] [hereafter referred to as organic $\mathrm{P}\left(\mathrm{P}_{\mathrm{o}}\right)$ ] was calculated as the difference between total $\mathrm{P}$ and inorganic $\mathrm{P}$. All chemicals used for soil analyses of $\mathrm{P}$ pools at least had the purity level for analysis.

\section{Soil analysis for $\mathrm{P}$ speciation}

Due to the relatively low P concentrations, especially in the subsoils that were not sufficient to yield $\mathrm{P} K$-edge XANES spectra with sufficient signal-to-noise ratio, all samples were relatively enriched in $\mathrm{P}$ by isolating the $<20 \mu \mathrm{m}$ size fraction (in agreement with [32], since most $\mathrm{P}$ is concentrated in the clay- to medium-silt-sized fraction [37]. In this way, we achieved a $P_{\text {tot }}$ enrichment by a factor of up to 6 compared with the bulk soil samples. This ensured a sufficient signal-to-noise ratio for all samples. P $K$-edge XANES spectra were collected using the Soft X-ray Microcharacterization Beamline (SXRMB) at the Canadian Light Source (CLS) in Saskatoon, Canada. Due to limited beamtime, only samples from the control and combined mineral + organic fertilization treatments were analyzed using $\mathrm{P} K$-edge XANES spectroscopy. The air-dried and homogenized samples were spread as a thin film onto a double-sided carbon tape and mounted onto a copper sample holder before being placed in the vacuum chamber. The spectra were recorded in fluorescence yield mode (samples) and total electron yield mode (reference standards), respectively, at photon energies between 2121 and $2215 \mathrm{eV}$. For each sample, at least two scans were recorded. Subsequent data treatment and evaluation, such as averaging of raw spectra (improving signal-tonoise ratio), background correction (pre-edge range: -20 to $6 \mathrm{eV}$ relative to $\mathrm{E} 0$ ), and normalization (normalization range: $+28 \mathrm{eV}$ to $+50 \mathrm{eV}$ normalization order: 2 ), as well as linear combination fitting (LCF), were performed using the ATHENA software package (Demeter 0.9.26) [51]. Linear combination fitting was performed on averaged, normalized spectra in the energy range between -12 and $+35 \mathrm{eV}$, relative to the E0. No floating of the E0 was allowed during fitting. Fitting was performed for all possible binary to quaternary combinations of the
11 most probable $\mathrm{P}$ reference standards in the sample: $\mathrm{CaHPO}_{4}, \mathrm{CaHPO}_{4} \times 2 \mathrm{H}_{2} \mathrm{O}, \mathrm{Ca}\left(\mathrm{H}_{2} \mathrm{PO} 4\right)_{2} \times \mathrm{H} 2 \mathrm{O}$, amorphous calcium phosphate (ACP), $\mathrm{AlPO}_{4}, \mathrm{FePO}_{4} \times 4 \mathrm{H}_{2} \mathrm{O}$, $\mathrm{P}$ adsorbed on gibbsite, $\mathrm{P}$ adsorbed on goethite, and $\left(\mathrm{C}_{6} \mathrm{H}_{18} \mathrm{O}_{24} \mathrm{P}_{6} \cdot \mathrm{Na} \cdot \mathrm{yH}_{2} \mathrm{O}\right)=$ phytic acid sodium salt hydrate). The $r$-factor values were used as goodness-offit criteria. Significance between fits was evaluated using the Hamilton test $(P<0.05)[14]$ with the number of independent data points calculated by Athena, estimated as data range divided by core-hole lifetime broadening. If, despite the addition of a further reference compound to a fit, the $r$-factor was not significantly better according to the Hamilton test, the fit with a lower number of reference compounds was chosen. If fits with the same number of reference compounds were not significantly different from each other, obtained proportions of the reference compounds and the $r$-factors of all significantly different fits were averaged. All chemicals used for XANES spectroscopy at least had the purity level for analysis. An exception to this was the standard $\mathrm{P}$ adsorbed on gibbsite and $\mathrm{P}$ adsorbed on goethite, as these compounds were produced by others $[2,25]$.

For ${ }^{31} \mathrm{P}$ NMR spectroscopy, the same treatments as for P $K$-edge XANES spectroscopy were analyzed. Sample preparation for the ${ }^{31} \mathrm{P}$ NMR measurement followed a procedure previously described in Cade-Menun et al. [13] and Turner [66]: $2 \mathrm{~g}$ of bulk soil were shaken for $4 \mathrm{~h}$ in $40 \mathrm{~mL}$ of $0.25 \mathrm{M} \mathrm{NaOH}-0.05 \mathrm{M}$ EDTA mixture at room temperature. After centrifugation at $14,000 \times g$ for $30 \mathrm{~min}$, the supernatant was frozen and lyophilized. $P$ recovery after extraction was summarized in Table 1. In total, $100 \mathrm{mg}$ of freeze-dried solids was redissolved in $500 \mu \mathrm{L}$ of a mixture of $\mathrm{NaOD}$ and $\mathrm{D}_{2} \mathrm{O}$ with a $\mathrm{pH}$ of 13. For quantification, $100 \mu \mathrm{L}$ of methylenediphosphonic acid solution (MDPA in $\mathrm{NaOD} / \mathrm{D}_{2} \mathrm{O}, 0.8 \mathrm{mg} \mathrm{mL}^{-1}$ ) was added as an internal reference standard [10]. The sample was centrifuged again at $14,000 \times g$ for $30 \mathrm{~min}$ and the supernatant was decanted into a 5-mm NMR tube. The NMR spectra were acquired on a Bruker $600 \mathrm{MHz}$ spectrometer equipped with a CryoProbe. Acquisition parameters were listed as follows: 0.55 acquisition time, 13,700 scans, inverse-gated proton decoupling, and $293.15 \mathrm{~K}$. Considering the sample was excited by a $30^{\circ}$ pulse calibrated at $4 \mu \mathrm{s}$, a 3-time T1 delay was required between each scan to ensure complete relaxation of all $\mathrm{P}$ nuclei [10]. The T1 of the individual sample was estimated based on the $\mathrm{P} /(\mathrm{Fe}+\mathrm{Mn})$ ratio [42]. For signal assignment, reference standards from Sigma Aldrich, including $\alpha$-, $\beta$-glycerophosphate, and myo-inositol hexakisphosphate (myo-IHP) were spiked into soil extracts. To identify RNA hydrolysis products, an RNA reference standard was deliberately hydrolyzed in a $\mathrm{NaOD} /$ $\mathrm{D}_{2} \mathrm{O}$ mixture and spiked into the soil extract. The NMR 
spectra were processed using MestReNova software (version 8.1.2-11880) with $2 \mathrm{~Hz}$ line broadening. All chemicals used for ${ }^{31} \mathrm{P}$ NMR spectroscopy at least had the purity level for analysis.

\section{Calculation of $P$ budgets}

The $\mathrm{P}$ budgets were calculated as follows:

$$
\mathrm{P} \text { budgets }=\mathrm{P}_{\mathrm{OF}}+\mathrm{P}_{\mathrm{MF}}-\mathrm{P}_{\text {Plant }} .
$$

The $\mathrm{P}$ input results from organic fertilization $\left(\mathrm{P}_{\mathrm{OF}}\right)$ and mineral fertilization $\left(\mathrm{P}_{\mathrm{MF}}\right)$, and $\mathrm{P}$ output results from $\mathrm{P}$ uptake by the harvested crop products $\left(\mathrm{P}_{\text {Plant }}\right)$. For the Dahlem experiment, the $\mathrm{P}$ budgets were calculated for 4 years from 2014 to 2017 using annual measurement data (crop yields, amount of farmyard manure, dry matter contents) and laboratory data ( $\mathrm{P}$ contents of harvested products and farmyard manure). As no information was available regarding $\mathrm{P}$ stocks in the topsoil and subsoils from the beginning of the long-term experiments, we had to calculate the theoretical initial $\mathrm{P}$ stocks by adding the $P$ budget (positive or negative) of the control treatment to measured P stocks of the control treatment. Using this value, we were then able to calculate the theoretical $P$ stocks that should be present in the soil, taking into account the $\mathrm{P}$ budgets for the entire duration of the longterm experimental trial by offsetting the $\mathrm{P}$ stocks of the treatments estimated for different profile depths with the P budgets (Additional file 1: Table S2). We were then able to estimate the deviation of the theoretical P stocks from the measured P stocks, while incorporating different soil depths (Additional file 1: Table S2).

\section{Yield response assessment}

To evaluate the relationship between the recorded crop yield data of all sites and the available soil $\mathrm{P}$ as determined by different methods $\left(\mathrm{P}_{\mathrm{DL}}, \mathrm{P}_{\mathrm{CAL}}\right.$, and $\left.\mathrm{P}_{\mathrm{DGT}}\right)$, we determined the maximum yield according to Mason et al. [41] by fitting the Mitscherlich equation:

$$
y=y_{\text {zero }}+a\left(1-e^{-\mathrm{bx}}\right),
$$

where $y_{\text {zero }}$ is the yield of the control and $y_{\text {zero }}+a$ is the maximum yield reached with the highest $\mathrm{P}$ application calculated using the model. The crop response to fertilization was determined by calculating the relative yield (\%) using the maximum yield calculated with Eq. (1):

$$
\text { relative yield }(\%)=\frac{y_{\text {zero }}}{y_{\text {zero }+a}} \times 100 \text {. }
$$

We included all sites and treatments for crop response modeling using the Mitscherlich equation (Eq. 2) within one fit [41]. To estimate the depth-dependent quality of the fit, we determined the Mitscherlich fit for three depth intervals separately, namely $0-30 \mathrm{~cm}, 0-60 \mathrm{~cm}$, and $0-90 \mathrm{~cm}$. In doing so, it is possible to estimate the contribution of the subsoil layers to crop prediction. The values of $\mathrm{P}_{\mathrm{DGT}}, \mathrm{P}_{\mathrm{DL}}$, and $\mathrm{P}_{\mathrm{CAL}}$ for Dahlem at depths of $30-50 \mathrm{~cm}$ and $50-70 \mathrm{~cm}$ were combined and included in the fits for the $0-60 \mathrm{~cm}$ depth of the other sites. We plotted soil $\mathrm{P}$ data $\left(\mathrm{P}_{\mathrm{DGT}}, \mathrm{P}_{\mathrm{CAL}}\right.$, or $\left.\mathrm{P}_{\mathrm{DL}}\right)$ against relative yields from Eq. (3) and used the obtained curve to estimate fitting parameters $y_{\text {zero }}+a$ and $b$. By inserting these fitting parameters and soil $\mathrm{P}$ data $\left(\mathrm{P}_{\mathrm{DGT}}, \mathrm{P}_{\mathrm{CAL}}, \mathrm{P}_{\mathrm{DL}}\right)$ into Eq. (2), we then obtained relative yield data as estimated by the Mitscherlich fit, $y_{\mathrm{fit}}$. The quality of the fit was estimated by correlating the $y_{\text {fit }}$ values with the values obtained through Eq. (3). Using this approach, it is then possible to evaluate the performance of different soil $P$ tests to estimate crop response to fertilization under field conditions.

\section{Statistical analyses}

Statistical analyses were performed using IBM SPSS 22 software (IBM SPSS Statistics V. 22.0, 2013, IBM Inc.). We tested total elemental concentrations, sequentially extracted $\mathrm{P}$ fractions, as well as $\mathrm{P}_{\mathrm{CAL}}, \mathrm{P}_{\mathrm{DL}}$, and $\mathrm{P}_{\mathrm{DGT}}$ for normal distribution using the Shapiro-Wilk test $(P<0.05)$ and for homogeneity of variances using the Brown-Forsythe test $(P<0.05)$. We considered samples from different depths as dependent samples. To account for this, we performed a 2-way repeated measures ANOVA, with fertilizer treatment as the 1st factor and depth intervals-treated as repeated measures-as the 2nd factor. If significant differences occurred, we used the Tukey HSD test for post hoc separation of means $(P<0.05)$. In addition, simple linear regression was performed correlating the values of $\mathrm{P}_{\mathrm{DL}}$ or $\mathrm{P}_{\mathrm{CAL}}$ with $\mathrm{P}_{\mathrm{DGT}}$. We determined correlations separately for the depth steps $0-30 \mathrm{~cm}, 0-60 / 70 \mathrm{~cm}$, and $0-90 \mathrm{~cm}$ analogous to the approach of the Mitscherlich fit described above. No statistical analyses were conducted for samples from Bad Lauchstädt, as no field replicates were available; therefore, differences between treatments and depths were pointed out as trends.

\section{Results \\ P budgets}

When comparing the measured P stocks with theoretical P stocks, the deviation was greatest in Bad Lauchstädt when only incorporating the topsoil $(0-30 \mathrm{~cm})$ with an underestimation of P stocks ranging from 12 to $46 \%$ (Additional file 1: Table S2). This deviation became lower by incorporating the other depth into the calculations and the smallest deviation was estimated by incorporating the 
complete soil profile from 0 to $90 \mathrm{~cm}$ (Additional file 1 : Table S2). However, in Rostock, no downward movement of P was observed [32] and thus the deviation was lowest when only considering the first $30 \mathrm{~cm}$ of the soil profile (Additional file 1: Table S2). In Dahlem, there was no difference in deviation when incorporating the subsoil layers, except for the organic P treatment.

\section{P fractions}

Total P stocks mostly did not reflect $\mathrm{P}$ fertilization in Dahlem and Freising Dürnast, while in Bad Lauchstädt, total P stock in the topsoil tended to increase after mineral $P$ and combined mineral+organic fertilization compared to the control (Additional file 1: Table S3). In comparison with the control, organic fertilization tended to increase not only the total P stocks of the topsoil but also the total P stocks in subsoils in Bad Lauchstädt. To highlight $\mathrm{P}$ pools of different availabilities in relation to total $\mathrm{P}$ stocks, we performed a sequential extraction. Hedley extractability (sum of extracted $P$ during sequential Hedley fractionation in relation to total $\mathrm{P}$ ) ranged from 18 to $53 \%$ for Dahlem, $60 \%$ to $101 \%$ for Dürnast, and $64 \%$ to $90 \%$ for Bad Lauchstädt. In general, stocks of stable $\mathrm{P}$ pools $\left(\mathrm{H}_{2} \mathrm{SO}_{4}-\mathrm{P}\right.$ and residual- $\left.\mathrm{P}\right)$ were greatest among all pools for all sites and treatments, followed by labile (resin-P, $\mathrm{NaHCO}_{3}-\mathrm{P}$ ) and moderately labile (NaOH-P) P pools (Additional file 1: Table S4, Fig. 1). With increasing soil depth, the labile and moderately labile stocks decreased, which to some extent was also reflected in their proportions on total P stocks (Additional file 1: Table S4, Fig. 1). The proportions of stable $\mathrm{P}\left(\mathrm{H}_{2} \mathrm{SO}_{4}-\mathrm{P}\right.$, Dahlem; $\mathrm{H}_{2} \mathrm{SO}_{4}-\mathrm{P}$ and residual- $\mathrm{P}$ (organic and mineral+organic $\mathrm{P}$ treatments), Bad Lauchstädt) tended to increase in deeper soil layers compared to the topsoil, but was only significant in a few cases (Additional file 1: Table S4). The treatment effects were less pronounced than the depth effects. There was a significant increase of $\mathrm{NaHCO}_{3}-\mathrm{P}_{\mathrm{i}}$ stocks after mineral $\mathrm{P}$ and combined mineral + organic $\mathrm{P}$ fertilization in the topsoil compared to the control, while $\mathrm{NaOH}-\mathrm{P}_{\mathrm{o}}$ stocks significantly increased in the topsoil after organic P fertilization in Dahlem. This increase in the $P_{o}$ of the topsoil after organic fertilization was also visible in Freising Dürnast for $\mathrm{NaOH}-\mathrm{P}_{\mathrm{o}}$, although the increase was not significant. These trends were visible in stocks as well as in proportions. In Bad Lauchstädt, treatments mostly affected labile inorganic $\mathrm{P}_{\mathrm{i}}\left(\right.$ resin- $\mathrm{P}, \mathrm{NaHCO}_{3}-\mathrm{P}_{\mathrm{i}}, \mathrm{NaOH}-\mathrm{P}_{\mathrm{i}}$ ), raising their stocks as well as proportions compared to the control for all depth layers (Additional file 1: Table S4, Fig. 1). $\mathrm{NaOH}-\mathrm{P}_{\mathrm{o}}$ (stocks and proportions) in Bad Lauchstädt also tended to increase in subsoil with combined mineral + organic fertilization. In addition, organic $\mathrm{P}$ fertilization tended to increase the $\mathrm{H}_{2} \mathrm{SO}_{4}-\mathrm{P}$ concentrations and proportions of the topsoil in Bad Lauchstädt. In summary, with the labile (resin- $\mathrm{P}, \mathrm{NaHCO}_{3}-\mathrm{P}$ ), moderately labile $(\mathrm{NaOH}-\mathrm{P})$, and stable $\left(\mathrm{H}_{2} \mathrm{SO}_{4}-\mathrm{P}\right.$ and residual-P) $\mathrm{P}$ pools, similar effects were visible as for single fraction stocks and proportions (Fig. 1).

In particular, the impacts on the labile P pool, which is known to reflect plant-available $P$ to a certain extent, is of interest after P fertilization. For this reason, we also determined $\mathrm{P}_{\mathrm{DGT}}$, which was highest in the topsoil for all sites, irrespective of fertilization treatment (Fig. 2). In addition, between treatments, significant effects were most prominent in the topsoil and the upper subsoil layer, except for Freising Dürnast, which only showed significant effects in the topsoil. The control treatment receiving no $P$ fertilization was mostly lowest in $P_{D G T}$ in Dahlem for the first and second soil depths, while there was no significant difference between the control and the fertilization treatments for the other sites. However, although not statistically tested, Bad Lauchstädt also exhibited the lowest $\mathrm{P}_{\mathrm{DGT}}$ in the control treatment for the first and second soil depths (Fig. 2). In addition, in Dahlem, the highest $\mathrm{P}_{\mathrm{DGT}}$ concentration was found for the mineral $P$ treatment in the topsoil $(0-30 \mathrm{~cm})$ and the upper subsoil layer $(30-50 \mathrm{~cm})$, while for the other subsoil layers, no significant differences were observed. The only significant treatment effect on $\mathrm{P}_{\mathrm{DGT}}$ in Freising Dürnast was that topsoil $\mathrm{P}_{\mathrm{DGT}}$ was the lowest among all treatments by a significant margin for organic $\mathrm{P}$ fertilization, including the control without $\mathrm{P}$ fertilization. For Bad Lauchstädt, no statistical analyses were possible. However, it seems that similar to Dahlem, the control treatment exhibited the lowest $\mathrm{P}_{\mathrm{DGT}}$ concentration and the mineral +organic $\mathrm{P}$ treatment the highest $\mathrm{P}_{\mathrm{DGT}}$ concentration in the two topsoil layers $(0-30 \mathrm{~cm}$ and $30-60 \mathrm{~cm}$ ). Similar findings were also made for the Rostock site with significantly higher $\mathrm{P}_{\mathrm{DGT}}$ concentrations in the mineral + organic $\mathrm{P}$ treatment in the topsoil $(0-30 \mathrm{~cm})$ and upper subsoil layer $(30-60 \mathrm{~cm})$, while all other treatments were not significantly different.

\section{Solution ${ }^{31} \mathrm{P}$ NMR spectroscopy}

The soil $\mathrm{P}_{\mathrm{o}}$ speciation was revealed by ${ }^{31} \mathrm{P}$ NMR analyses after extraction with the $\mathrm{NaOH}-\mathrm{EDTA}$ mixture. P recovery after extraction, which appears to be higher in topsoils than subsoils, ranged between 10 and $64 \%$ relative to $\mathrm{P}_{\mathrm{t}}$ stock (Table 1). In the monoester region, the signals of $\alpha-, \beta$-glycerophosphate, and myo-IHP were identified by spiking experiments, while the spiking of RNA hydrolysis products did not correspond to any signals (Additional file 1: Figs. S2, S3). The signals at $4.1 \mathrm{ppm}$ and $6.8 \mathrm{ppm}$ were assigned to scyllo-IHP and isomerized IHP, respectively $[68,69]$. Freising Dürnast and Dahlem soils showed similar monoester composition, with all predominant 

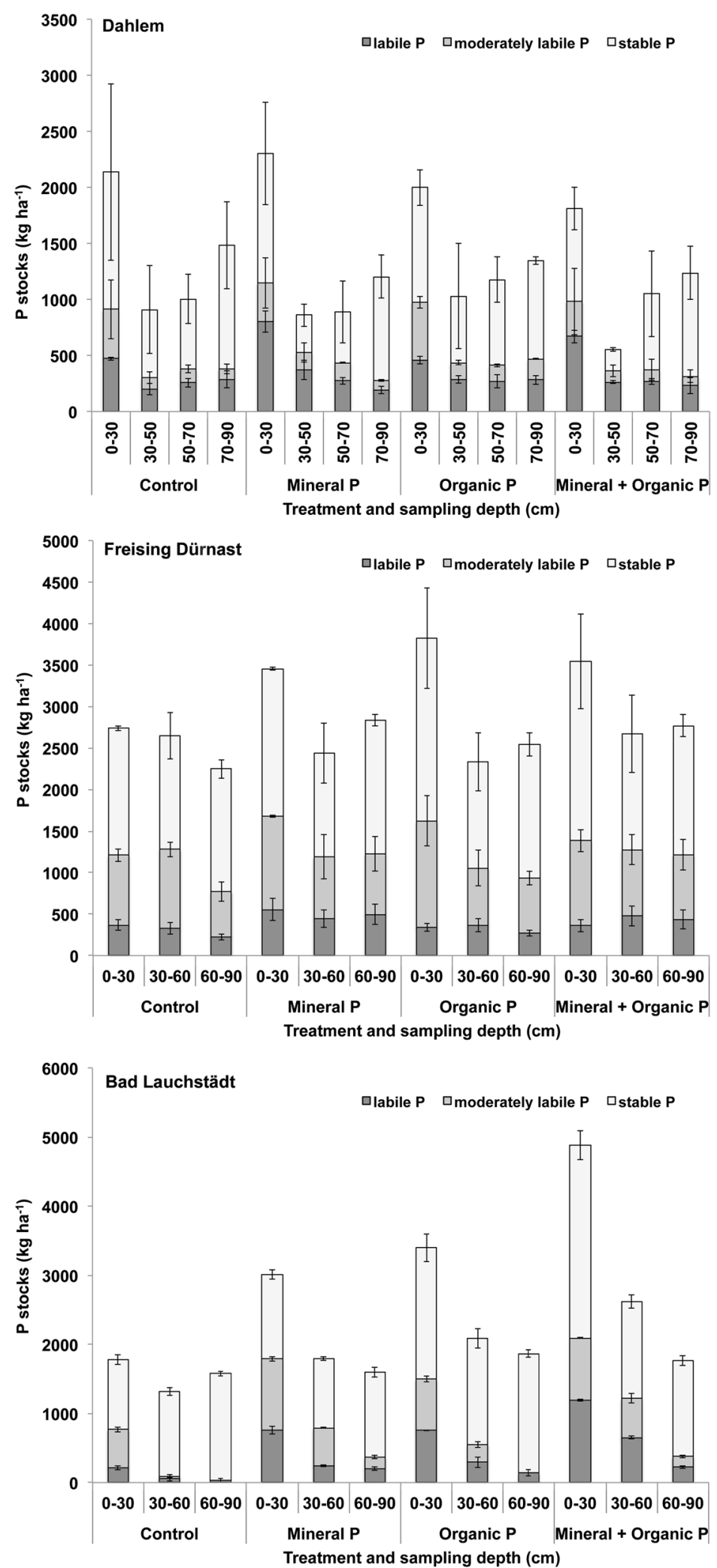

Fig. 1 Stock of labile (Resin-P, $\left.\mathrm{NaHCO}_{3}-\mathrm{P}_{\mathrm{i}, 0}\right)$, moderately labile $\left(\mathrm{NaOH}-\mathrm{P}_{\mathrm{i}, 0}\right)$, and stable $\left(\mathrm{H}_{2} \mathrm{SO}_{4}-\mathrm{P}_{\mathrm{t}}\right.$ and Residual- $\left.\mathrm{P}_{\mathrm{t}}\right) \mathrm{P}$ fractions. Samples were obtained from the long-term experimental sites Dahlem, Freising Dürnast, and Bad Lauchstädt at different soil depths. Error bars represent standard deviations of the mean $(n=3)$ 


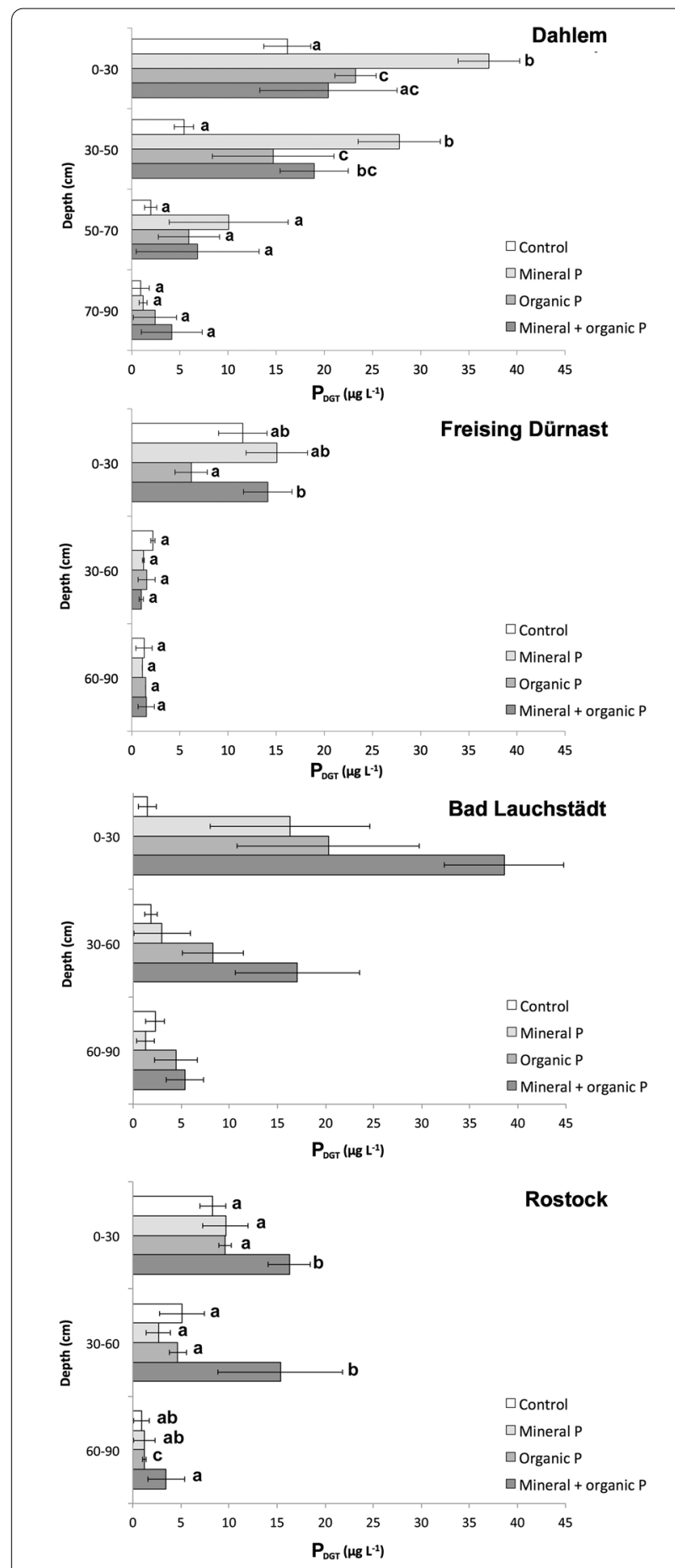

Fig. 2 Plant available $P$ concentration as determined by the diffusive gradients in thin films (DGT) approach. Samples were obtained from the long-term experimental sites Dahlem, Freising Dürnast, Bad Lauchstädt, and Rostock at different soil depths. Different lowercase letters indicate significant differences among treatments within each soil depth $(P<0.05)$. Error bars represent standard deviations of the mean $(n=3)$. No statistical analysis could be conducted for samples from Bad Lauchstädt as no field replicates were available signals from myo- and scyllo-IHP. In Bad Lauchstädt, the myo-IHP signals were weak but a strong unknown signal was observed at $4.4 \mathrm{ppm}$. The signals of $\alpha-, \beta-$ glycerophosphate were low and considered as hydrolyzed phospholipids for quantification (Table 1).

A trend of decreasing $\mathrm{P}$ recovery with increasing sampling depth was observed, especially for Dahlem and Bad Lauchstädt. The soil P pool at the Dahlem site was mostly inorganic, with orthophosphate accounting for $80-100 \%$ of $\mathrm{P}_{\mathrm{t}}$. For the other two sites, the proportion of orthophosphate, although lower than Dahlem, was still the most abundant $\mathrm{P}$ form (39-82\%) followed by monoesters (17-59\%). Phosphonate, diesters, and pyrophosphate were only detected in small proportions and were not present in all samples (Table 1, Additional file 1: Figs. S4-S9). Polyphosphate was not detected in any of the soils.

In all samples, the contents of orthophosphate and extractable $\mathrm{P}_{\mathrm{o}}$ were highest in the topsoil and gradually decreased with depth (with a few exceptions at Freising Dürnast). The content of pyrophosphate was also higher in the topsoil than in the layers below. The proportions of orthophosphate and extractable $\mathrm{P}_{\mathrm{o}}$ only showed a clear depth-dependent trend at Dahlem; no such trend was observed at Freising Dürnast and Bad Lauchstädt.

Compared to the control plots, the extractable $P_{t}$ content in both topsoils and subsoils increased after the application of fertilizer, especially in Bad Lauchstädt soils where the most pronounced $\mathrm{P}$ enrichment effect was observed. In addition, the growth in extractable $P_{t}$ stocks after fertilizer treatment was mostly attributed to orthophosphate, since only the orthophosphate proportion increased, while the share of other P categories such as monoesters declined. At Bad Lauchstädt, fertilization decreased the $\mathrm{P}_{\mathrm{o}}$ content in the topsoil, but the opposite effect was observed in subsoils. At the other two sites, the effect of fertilization on total $\mathrm{P}_{\mathrm{o}}$ content was unclear.

\section{P-XANES analyses}

The LCF of the P $K$-edge spectra (Additional file 1: Fig. S10) indicated that the Dahlem and Freising Dürnast sites were dominated by Fe-associated P (26-73\%), while soils in Bad Lauchstädt were dominated by Ca-associated $\mathrm{P}(27-56 \%)$. The proportions of organic-associated P were lowest in Dahlem (3-10\%), whereas significant proportions were found for Freising Dürnast (15-27\%) and Bad Lauchstädt (17-27\%) (Table 2). It should be noted that focusing on the $<20 \mu \mathrm{m}$ size fraction might also have resulted in a shift in the $P_{i} / P_{o}$ ratio due to a higher relative enrichment of $\mathrm{P}_{\mathrm{o}}$ compounds, which are known to associate and accumulate in the clay- to the medium-sized silt fraction [37]. Treatment effects were not consistent among sites. No clear treatment effect was 
Table 1 Depth resolved phosphorus (P) stocks and the composition of $\mathrm{NaOH}$-EDTA extractable soil $\mathrm{P}$, as assessed by the liquid ${ }^{31} \mathrm{P}$ NMR spectroscopy of homogenized composite samples $(n=3)$ of three long-term experimental sites

\begin{tabular}{|c|c|c|c|c|c|c|c|c|c|}
\hline \multirow[t]{3}{*}{ Management } & \multirow[t]{2}{*}{ Depth } & \multirow{2}{*}{ P recovery } & \multirow{2}{*}{$\begin{array}{l}\text { Phosphonate } \\
>20 \mathrm{ppm}\end{array}$} & \multirow{3}{*}{$\begin{array}{l}\text { Orthophophate } \\
6.7 \text { to } 6.0 \mathrm{ppm}\end{array}$} & \multirow{3}{*}{$\begin{array}{l}\text { Monoesters } \\
6.9 \text { to } 6.7,6.0 \\
\text { to } 3.5 \mathrm{ppm}\end{array}$} & \multirow{3}{*}{$\begin{array}{l}\text { Diesters } \\
2 \text { to }-2 \mathrm{ppm}\end{array}$} & \multirow{3}{*}{$\begin{array}{l}\text { Pyrophosphate } \\
-4.3 \text { ppm }\end{array}$} & \multirow[t]{3}{*}{ Extractable $\mathrm{P}_{\mathrm{o}}$} & \multirow[t]{3}{*}{ Extractable $P_{t}$} \\
\hline & & & & & & & & & \\
\hline & $\mathrm{cm}$ & $\%$ & $\mathrm{~kg} \mathrm{ha}^{-1}(\%)$ & & & & & & \\
\hline \multicolumn{10}{|l|}{ Dahlem } \\
\hline \multirow[t]{3}{*}{ Control } & $0-30$ & 30 & $0.0(0)$ & $627(80)$ & $144(18)$ & $4.5(0.6)$ & $6.2(0.8)$ & $148(19)$ & 781 \\
\hline & $30-50$ & 19 & $0.0(0)$ & $191(96)$ & $8(4)$ & $0.0(0)$ & $0.0(0)$ & $8(4)$ & 199 \\
\hline & $70-90$ & 10 & $0.0(0)$ & $172(100)$ & $0.0(0)$ & $0.0(0)$ & $0.0(0)$ & 0 & 172 \\
\hline \multirow[t]{3}{*}{ Mineral + organic $P$} & $0-30$ & 45 & $0.0(0)$ & $989(85)$ & $162(14)$ & $3.3(0.3)$ & $6.8(0.6)$ & $166(14)$ & 1162 \\
\hline & $30-50$ & 51 & $0.0(0)$ & $410(98)$ & $10(2)$ & $0.0(0)$ & $0.0(0)$ & $10(2)$ & 420 \\
\hline & $70-90$ & 15 & $0.0(0)$ & $186(100)$ & $0.0(0)$ & $0.0(0)$ & $0.0(0)$ & 0 & 186 \\
\hline \multicolumn{10}{|l|}{ Freising Dürnast } \\
\hline \multirow[t]{3}{*}{ Control } & $0-30$ & 57 & $0.0(0)$ & $825(67)$ & $392(32)$ & $6.8(0.6)$ & $9.2(0.7)$ & $398(32)$ & 1233 \\
\hline & $30-60$ & 40 & $3.5(0.4)$ & $477(50)$ & $461(49)$ & $1.9(0.2)$ & $6.2(0.7)$ & $466(49)$ & 949 \\
\hline & $60-90$ & 47 & $0.0(0)$ & $557(62)$ & $339(38)$ & $0.0(0)$ & $4.9(0.5)$ & $339(38)$ & 901 \\
\hline \multirow[t]{3}{*}{ Mineral + organic $P$} & $0-30$ & 64 & $3.1(0.2)$ & $1187(72)$ & $442(27)$ & $5.8(0.3)$ & $10.2(0.6)$ & $451(27)$ & 1648 \\
\hline & $30-60$ & 37 & $2.2(0.2)$ & $514(52)$ & $454(46)$ & $3.7(0.4)$ & $5.3(0.5)$ & $460(47)$ & 979 \\
\hline & $60-90$ & 48 & $0.0(0)$ & $787(68)$ & $358(31)$ & $0.0(0)$ & $4.9(0.4)$ & $358(31)$ & 1150 \\
\hline \multicolumn{10}{|l|}{ Bad Lauchstädt } \\
\hline \multirow[t]{3}{*}{ Control } & $0-30$ & 39 & $0.0(0)$ & $336(46)$ & $386(53)$ & $2.7(0.4)$ & $8.4(1.1)$ & $388(53)$ & 733 \\
\hline & $30-60$ & 28 & $0.0(0)$ & $117(39)$ & $177(59)$ & $3.4(1.1)$ & $1.0(0.3)$ & $180(60)$ & 299 \\
\hline & $60-90$ & 11 & $0.0(0)$ & $54(52)$ & $50(48)$ & $0.0(0)$ & $0.0(0)$ & $50(48)$ & 103 \\
\hline \multirow[t]{3}{*}{ Mineral + organic $P$} & $0-30$ & 56 & $0.0(0)$ & 1554 (82) & $328(17)$ & $9.4(0.5)$ & $9.0(0.5)$ & $338(18)$ & 1901 \\
\hline & $30-60$ & 39 & $0.0(0)$ & 750 (71) & $299(28)$ & $5.7(0.5)$ & $4.0(0.4)$ & $305(29)$ & 1059 \\
\hline & $60-90$ & 35 & $0.0(0)$ & $384(67)$ & $187(33)$ & $1.3(0.2)$ & $0.0(0)$ & $189(33)$ & 572 \\
\hline
\end{tabular}

The values in parentheses (\%) represent the individual P forms as a proportion of total NaOH-EDTA extractable soil P. The content of diesters and monoesters were corrected by considering $\mathrm{P}$ hydrolysis during extraction

observed for Freising Dürnast. By contrast, in Dahlem, mineral+organic $\mathrm{P}$ fertilization resulted in a relative decrease in $\mathrm{Fe}$-associated $\mathrm{P}$ in favor of $\mathrm{Al}$ in the topsoil, whereas organic-associated $\mathrm{P}$ remained the same. In the subsoil, $\mathrm{P}$ speciation was very similar to the control and a possible treatment effect was only indicated by an increase in organic-associated $\mathrm{P}$ in both subsoil layers. A decrease in $\mathrm{Fe}$-associated $\mathrm{P}$ in favor of $\mathrm{Al}$-associated $\mathrm{P}$ relative to the control was also observed in the topsoil in Bad Lauchstädt. However, in contrast to Dahlem, organic-associated $\mathrm{P}$ here decreased in the topsoil whereas Ca-associated P increased. In the subsoil, mineral and organic $\mathrm{P}$ fertilization only affected proportions in Bad Lauchstädt, with generally decreasing proportions of $\mathrm{P}$ associated with $\mathrm{Ca}-\mathrm{P}$ and increasing proportions of organic-associated $\mathrm{P}$ at a depth of $60-90 \mathrm{~cm}$, while it remained similar at a depth of $30-60 \mathrm{~cm}$ (Table 2).

\section{Crop yield response}

The stocks of the DL extractable $\mathrm{P}\left(\mathrm{P}_{\mathrm{DL}}\right)$ and CAL extractable $\mathrm{P}\left(\mathrm{P}_{\mathrm{CAL}}\right)$ (Additional file 1: Table S5) for all three sites (Dahlem, Freising Dürnast, Bad Lauchstädt) followed the same trend as $\mathrm{P}_{\mathrm{DGT}}$ (Additional file 1: Table S5, Fig. 2).
When correlating $\mathrm{P}_{\mathrm{DL}}$ or $\mathrm{P}_{\mathrm{CAL}}$ with $\mathrm{P}_{\mathrm{DGT}}$ significant positive linear relationships were found for both $\mathrm{P}_{\mathrm{DL}}$ and $\mathrm{P}_{\mathrm{CAL}}$ for the individual depths of $0-30 \mathrm{~cm}, 0-60 / 70 \mathrm{~cm}$, and $0-90 \mathrm{~cm}$ with $R^{2}$ ranging between 0.27 and 0.60 . The coefficient of determination was throughout higher for $\mathrm{P}_{\mathrm{CAL}}$ than for $\mathrm{P}_{\mathrm{DL}}$ (Fig. 3). Incorporating the subsoil had no effect on $\mathrm{P}_{\mathrm{DL}}$ and $\mathrm{P}_{\mathrm{DGT}}$ regression, but resulted in higher $\mathrm{R}^{2}$ for $\mathrm{P}_{\mathrm{CAL}}$ and $\mathrm{P}_{\mathrm{DGT}}$ regressions.

Rostock, Dahlem, and Bad Lauchstädt were responsive to $P$ fertilization, i.e. crop yields were significantly higher for the highest $\mathrm{P}$ fertilizer application level compared to the control treatment (Additional file 1: Table S6). Therefore, using Eq. 2, maximum yields were estimated at $119 \mathrm{dt} \mathrm{ha}^{-1}$ (maize), $7 \mathrm{dt} \mathrm{ha}^{-1}$ (winter rye), and $60 \mathrm{dt} \mathrm{ha}^{-1}$ (spring barley) for Rostock, Dahlem, and Bad Lauchstädt, respectively. Freising Dürnast did not show significantly higher crop yields with the highest $\mathrm{P}$ application level (Additional file 1: Table S6). We therefore determined the maximum yield through the application of all P levels except the control treatment. We thus obtained a mean value of $127 \mathrm{dt} \mathrm{ha}^{-1}$ (maize). In doing so, we included all sites and treatments for crop response modeling using the Mitscherlich equation (Eq. 2) [41]. Crop response to 


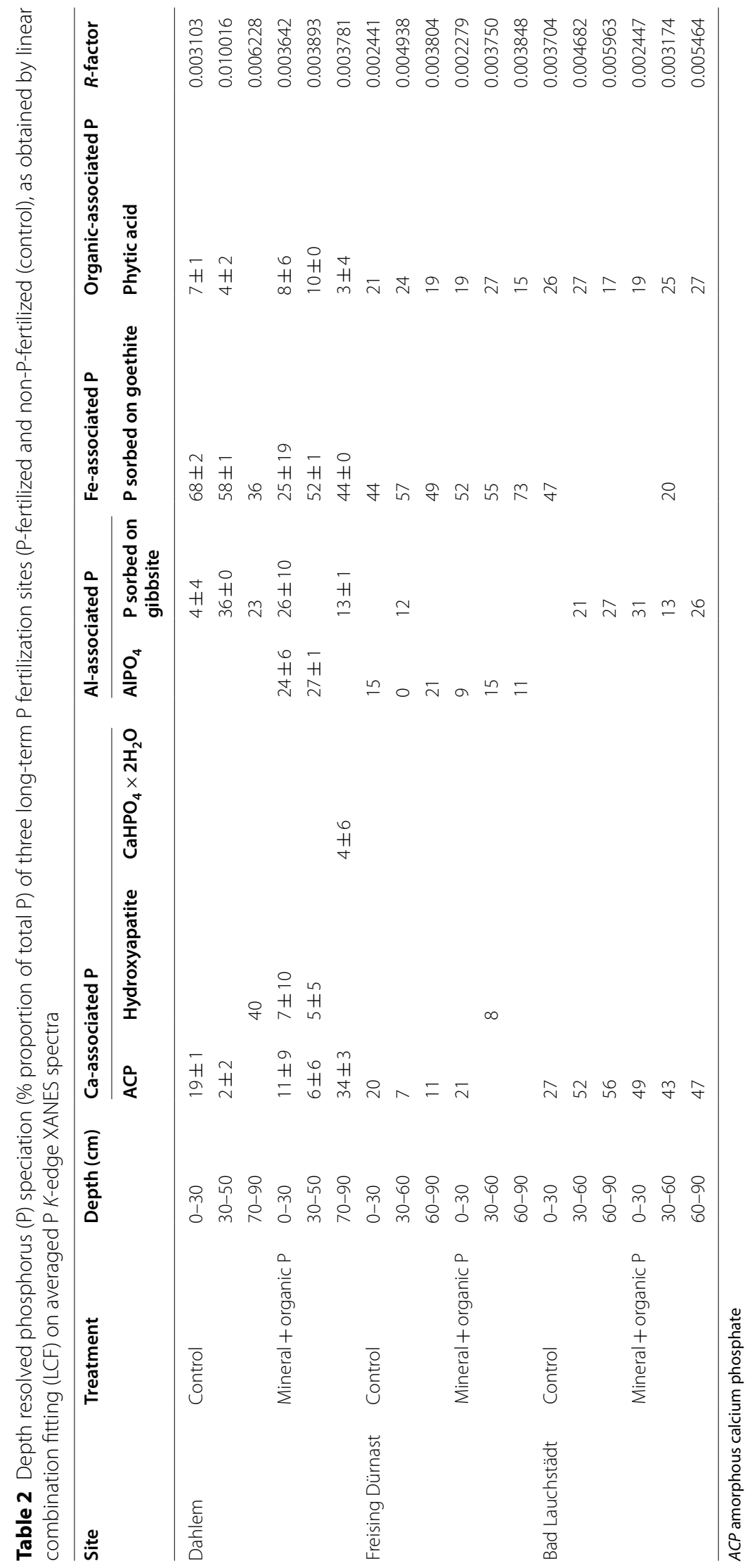


applied fertilizer P was modeled well, including all sites and treatments, using the Mitscherlich relationship for three soil P tests for the topsoil, whereas fitting became worse when subsequently adding deeper soil layers to the fit (Fig. 4, Additional file 1: Table S7). The best and significant coefficients of determination for the regression fits $R^{2}$ were obtained for $\mathrm{P}_{\mathrm{DGT}}$, followed by $\mathrm{P}_{\mathrm{CAL}}$, while fits for $\mathrm{P}_{\mathrm{DL}}$ were the worst (Fig. 4).

\section{Discussion}

\section{Influence of fertilization on $\mathrm{P}$ stocks and pools}

The increasing $P$ stock with fertilization in Bad Lauchstädt was also found by others [44]. The increase was anticipated, as there was a positive $\mathrm{P}$ budget calculated for the mineral (1299 kg ha $\left.{ }^{-1}\right)$, organic $\left(214 \mathrm{~kg} \mathrm{ha}^{-1}\right)$, and combined mineral + organic fertilization $\left(2921 \mathrm{~kg} \mathrm{ha}^{-1}\right)$, whereas the control treatment had a negative $\mathrm{P}$ budget $\left(-1569 \mathrm{~kg} \mathrm{ha}^{-1}\right)$ until the time of soil sampling [44, 75]. In contrast, in Freising Dürnast, unchanged topsoil $\mathrm{P}$ stocks after organic P fertilization were surprising, as the $\mathrm{P}$ budget for the control was $-1105 \mathrm{~kg} \mathrm{ha}^{-1}$ and the budget of, for example, the mineral $\mathrm{P}$ treatment was $324 \mathrm{~kg} \mathrm{ha}^{-1}$ for an experimental duration of 37 years. Significantly increased P stocks had been anticipated for that treatment (Additional file 1: Table S3). Zicker et al. [79] attributed the gap in P budgets and the topsoil $P$ stocks to the potential of the plant to also acquire $\mathrm{P}$ from deeper soil layers and the downward movement of fertilizer P from upper soil layers, which is assumed to apply here.

An uptake from deeper soil layers and especially a downward movement of fertilizer $\mathrm{P}$ was also indicated in the data of Freising Dürnast and even more pronounced in the data of Bad Lauchstädt for this study. When considering the DPS-indicating the risk of P losses-the topsoil DPS in particular was $>30 \%$ for the Dürnast and Bad Lauchstädt sites for treatments receiving P (Additional file 1: Fig. S1), indicating a risk of applied P leaching into subsoil layers. At both sites, organic as well as combined mineral +organic $\mathrm{P}$ fertilization tended to increase total P stocks (although not significantly) in the subsoils compared to the unfertilized control, which was most pronounced for the combined fertilization (Additional file 1: Table S3). In the literature, the same trends for the application of organic fertilizers were found for other long-term experimental sites [22, 39]. The authors attributed the downward leaching of $\mathrm{P}$ after organic fertilization to the co-leaching of $\mathrm{P}$ complexing compounds or compounds released from organic fertilizer that compete with the organic fertilizer-derived $\mathrm{P}$ for sorption sites $[28,52]$. This also explains our observation that the combined mineral + organic P fertilization in particular facilitates a downward movement of fertilizer P. Among the three tested sites, the enrichment of $P$ in the subsoils was highest in Bad Lauchstädt, followed by Freising Dürnast, whereas no enrichment was observed at Dahlem, despite the fact that DPS was $>40 \%$ (Additional file 1: Fig. $\mathrm{S} 1$ ). This suggests that the extent of the downward movement and enrichment of $\mathrm{P}$ in the subsoil appears to be site-specific.

Possible site-specific factors are, for example, the amount of applied P vs. plant P uptake, the duration of the experiment, and soil properties. For this study, it is very likely that besides duration-which particularly increases the contrast between control and $\mathrm{P}$ treatments - the variations in soil properties between the sites are the main driving factors. The Retisol of Dahlem with the clay-enriched argic subsoil horizon may have limited a downward movement of $\mathrm{P}$ into deeper subsoil layers. By contrast, in the Cambisol in Freising Dürnast, and especially the Chernozem in Bad Lauchstädt (well-structured, and pore-rich chernic horizon down to $60 \mathrm{~cm}$ ), the downward movement of water is facilitated.

If these considerations are correct, not only the topsoil but also the subsoil must be considered when calculating the P budgets. The greatest deviation from theoretical P stocks found for Bad Lauchstädt when only incorporating the topsoil $(0-30 \mathrm{~cm}$ ) (Additional file 1: Table S2) is a result of the downward movement of $P$ due to the chernic horizon down to $60 \mathrm{~cm}$. In Dahlem, a downward movement of $\mathrm{P}$ was mostly prevented due to the clay-enriched subsoil horizons starting at a depth of $\sim 60 \mathrm{~cm}$. Therefore, no distinct trend for the extent of deviation was observed when incorporating different soil layers. Another important factor is the existing duration of the fertilization regime. Prior to the time of sampling, the experimental site Bad Lauchstädt had been managed for 113 years, whereas the site in Rostock was only established 16 years ago, explaining the lowest deviations when only considering the topsoil. The factors soil properties and time were also reflected when comparing Rostock with Freising Dürnast. Both soils are Cambisols but the deviation

(See figure on next page.)

Fig. 3 Relationship between $P_{D L}$ and $P_{C A L}$ concentrations and $P_{D G T}$ concentrations. Analyses were conducted for all treatments (control, mineral P, organic P, mineral + organic P), all experimental sites (Dahlem, Freising Dürnast, Bad Lauchstädt, Rostock), and the sampling depths $0-30 \mathrm{~cm}$, $0-60 / 70 \mathrm{~cm}$, and $0-90 \mathrm{~cm}$. Significant correlations were highlighted with ${ }^{*}(P<0.05),{ }^{* *}(P<0.01)$, and ${ }^{* * *}(P<0.001)$. DL double-lactate, CAL calcium acetate lactate, DGT diffusive gradients in thin films 

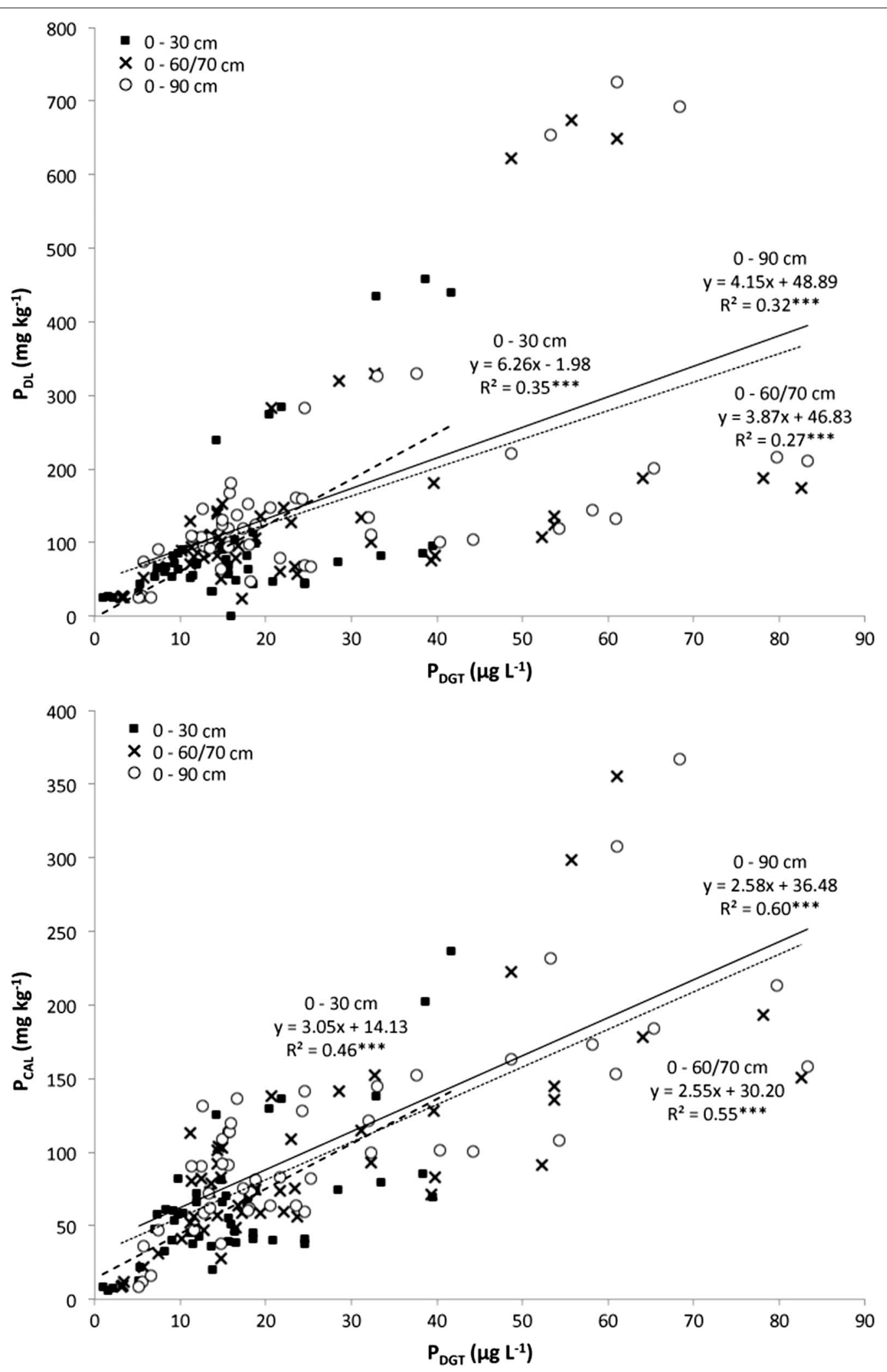

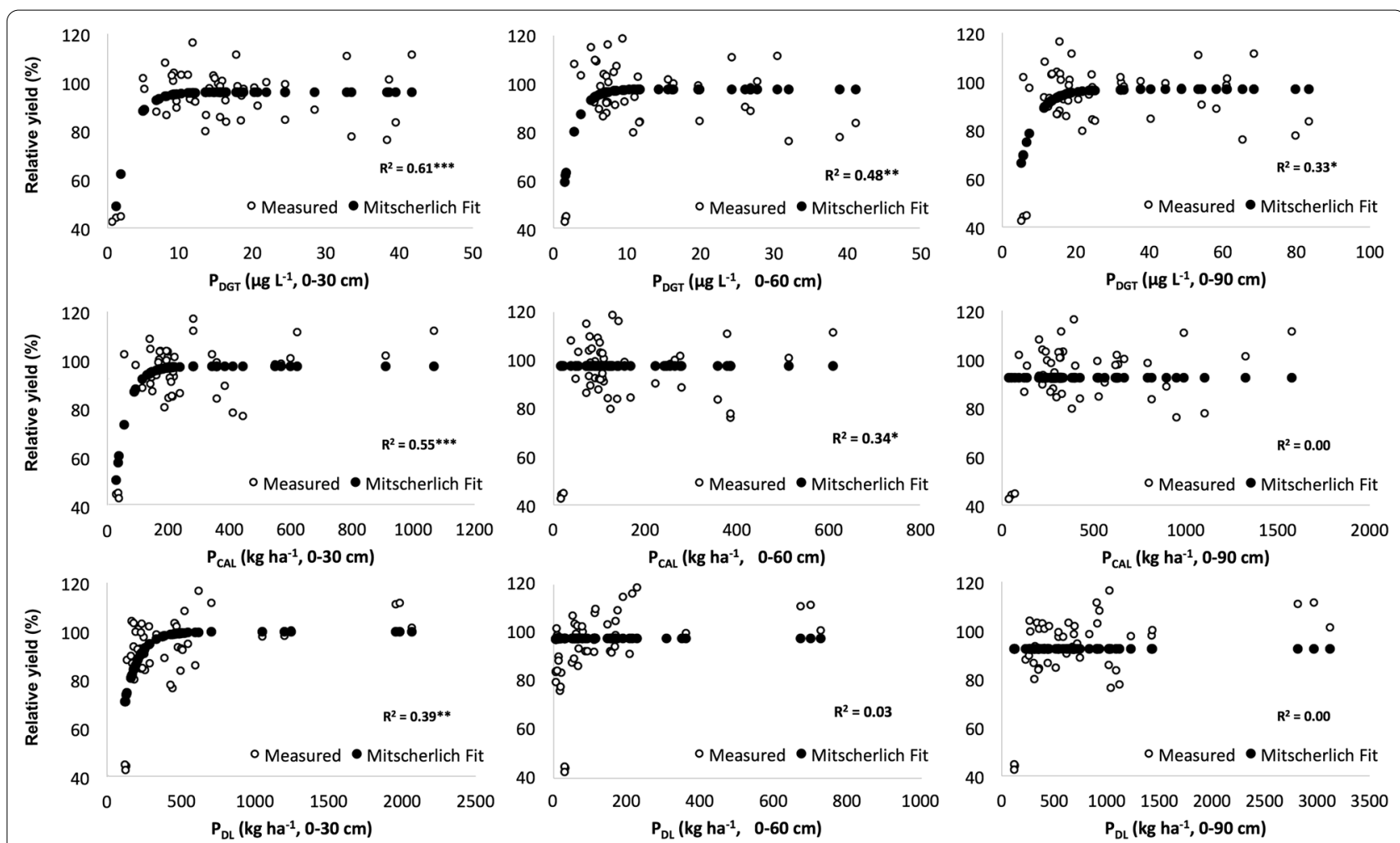

Fig. 4 Mitscherlich relationship of plant-available soil $P(D L, C A L$, and $D G T$ ) with crop response. $n=48$; response was modeled using the Mitscherlich equation. Significant coefficients of determination $\left(R^{2}\right)$ were highlighted with ${ }^{*}(P<0.05)$, ${ }^{*}(P<0.01)$, and ${ }^{* *}(P<0.001)$. DL double-lactate, CAL calcium acetate lactate, DGT diffusive gradients in thin films

in Freising Dürnast remained the same or even became 0 for the combined mineral + organic P treatment when incorporating the complete soil profile sampled, most likely an effect of the longer duration of this experiment (16 vs. 37 years). These results demonstrate that for $\mathrm{P}$ budget calculations, several parameters have to be taken into account when evaluating P fertilization strategies. Fertilization mostly increased the proportion of $\mathrm{P}$ stored in the topsoil. The P fertilization not only affected the distribution of total $\mathrm{P}$ stocks along the soil profile, but also different $\mathrm{P}$ pools to a certain extent. For example, the increase of $\mathrm{NaOH}-\mathrm{P}_{\mathrm{o}}$ in the topsoil after organic $\mathrm{P}$ fertilization and partial increase of $\mathrm{H}_{2} \mathrm{SO}_{4}-\mathrm{P}$ (Bad Lauchstädt) (Additional file 1: Table S4) was anticipated due to the introduction of organic materials also incorporating occluded $P_{i}$ and $P_{o}$, i.e. stable humic acids and larger humus complexes or monoesters that are covered or physically encapsulated $[5,17,32,73]$. However, a change in the $\mathrm{P}$ fractions of the subsoil was not very pronounced.

Mineral P fertilizers (alone or in combination with organic fertilizers) affected $\mathrm{P}_{\mathrm{i}}$ fractions in all soil depths, but were always most pronounced in the topsoil. This was mainly visible in the labile $\mathrm{P}$ pool $\left(\mathrm{H}_{2} \mathrm{O}-\mathrm{P}_{\mathrm{i}}+\mathrm{NaHCO}_{3}-\right.$ $\mathrm{P}_{\mathrm{i}}$ ), but it was also reflected in $\mathrm{P}_{\mathrm{DGT}}$ at the Bad Lauchstädt and Rostock sites and in $\mathrm{P}_{\mathrm{DL}}$ and $\mathrm{P}_{\mathrm{CAL}}$ at Bad Lauchstädt for the mineral+organic treatment (Fig. 2, Additional file 1: Table S5). The fact that in Bad Lauchstädt, the mineral + organic P fertilizer was more effective in increasing labile $\mathrm{P}$ (labile $\mathrm{P}_{\mathrm{i}}, \mathrm{P}_{\mathrm{DGT}}, \mathrm{P}_{\mathrm{DL}}$, and $\mathrm{P}_{\mathrm{CAL}}$ ) than the mineral $\mathrm{P}$ alone is likely due to the fertilization history of the plot with higher application levels until 1981 (Additional file 1: Table S1). This also applies to the Rostock site with $\mathrm{P}$ application levels above plant requirements for the combined mineral + organic P treatment [32].

Furthermore, a possible competition for sorption sites between fertilizer $\mathrm{P}_{\mathrm{i}}$ and organic anions and acids released during the decomposition of the organic fertilizers $[32,52]$ increases the soluble soil $\mathrm{P}$ pool. There is also a clear difference between the types of organic fertilizer visible in $\mathrm{P}_{\mathrm{DGT}}$ concentrations. While the application of green manure or just compost (also containing substantial amounts of green waste; [32]) decreased the $\mathrm{P}_{\mathrm{DGT}}$ concentration of the topsoil by $-46 \%$ (Freising Dürnast) or only slightly increased it by $14 \%$ (Rostock), the application of farmyard manure substantially increased the $\mathrm{P}_{\mathrm{DGT}}$ concentrations of the topsoil by $30 \%$ in Dahlem and by $86 \%(0-60 \mathrm{~cm})$ in Bad Lauchstädt. These results support findings made by other scientists, claiming that soils 
amended with manure exhibited higher plant-available $\mathrm{P}$ than soils receiving compost [22].

The sites receiving green manure or compost (Freising Dürnast and Rostock) both exhibited comparable P proportions distributed among $\mathrm{P}$ fractions, which can be attributed to both soils being Cambisols (Additional file 1: Table S4, [32]). For both sites, treatment effects were also less pronounced and mostly insignificant, including with respect to inorganic $\mathrm{P}$ fractions like $\mathrm{P}_{\mathrm{DGT}}$. Koch et al. [32] concluded that 16 years of continuous fertilization in Rostock was not a sufficient period of time to lead to pronounced management-induced differences in P fractions, which might also apply to Freising Dürnast with 37 years of continuous fertilization management prior to the time of soil sampling.

\section{Influence of fertilization on phosphorus speciation}

Current $\mathrm{P}$ research still lacks a complete understanding on the extent to which the P forms present in the topsoil and subsoil are physically accessible and chemically available to the crop [29, 35, 64]. The use of soil depthresolved sequential $\mathrm{P}$ fractionation in combination with spectroscopic methods helped to show how $\mathrm{P}$ forms at the molecular level are influenced by fertilization management.

Using ${ }^{31} \mathrm{P}$ NMR spectroscopy, we found a decreasing $\mathrm{P}$ extractability ( $\mathrm{NaOH}-\mathrm{EDTA}$ extraction) with increasing soil depth (Table 1), which is consistent with previous studies [22, 32, 55]. The dominance of orthophosphate stocks, regardless of the soil type or the crop rotation, was in line with other studies $[1,32]$. Along the soil profile, the degree of the accumulation of $\mathrm{NaOH}-\mathrm{EDTA}$ extractable $P_{i}$ and $P_{o}$ forms was site-specific. This can be explained by the differences in the amount of applied $\mathrm{P}$ and the differences between the duration of the field experiments, which both potentially intensify contrasts of the P fertilization effects in the soil profile [22]. For instance, relatively small changes in the $\mathrm{NaOH}-\mathrm{EDTA}$ extractable $\mathrm{P}_{\mathrm{i}}$ and $\mathrm{P}_{\mathrm{o}}$ stocks along the soil profile relative to the control were found in Freising Dürnast, which corresponds to the shortest duration among all three sites until time of sampling (36 vs. 92 or 113 years).

In general, similar to labile $\mathrm{P}$ and $\mathrm{P}_{\mathrm{DGT}}$, the orthophosphate stocks were the highest in topsoils and gradually decreased with depth (Figs. 1 and 2, Table 1), thus confirming that there are larger stocks of labile $\mathrm{P}$ in the topsoils than in the subsoil. Furthermore, the increase in stocks of orthophosphate in the subsoil after fertilization treatment in relation to the control supports a downward movement of labile $\mathrm{P}_{\mathrm{i}}$, which also applied for monoesters in the subsoil, especially at the Bad Lauchstädt site.

Monoesters in the topsoil at Bad Lauchstädt were hardly influenced by $\mathrm{P}$ fertilization, likely indicating a balance between the input, mineralization, and stabilization of $\mathrm{NaOH}$-EDTA extractable monoesters after 113 years of management. Therefore, the retention capacity of topsoil for monoesters appears saturated, facilitating the leaching of surplus monoesters into the subsoil. However, our data suggest that the observed difference in the accumulation patterns of ortho-P monoesters along the soil profiles between Freising Dürnast, Bad Lauchstädt, and Dahlem was also influenced by the above-mentioned site-specific soil properties at Dahlem restricting the transport of $\mathrm{P}$ into deeper subsoil layers.

The abundance of diesters, even after including their hydrolysis products, was generally low in all soils. By contrast, monoesters $(0-59 \%)$ were the dominant $\mathrm{P}_{\mathrm{o}}$ form over dieters $(0-1.1 \%)$, which was in agreement with other studies on arable soils [16, 32, 43]. It reflected an enhanced mineralization of the labile diester-P due to cultivation practices. For example, [63] showed that cropping and fertilizer input limited $\mathrm{P}_{\mathrm{o}}$ diversity in temperate arable soils.

The difference in $\mathrm{P}_{\mathrm{o}}$ speciation in the topsoil was more pronounced between sites, rather than between treatments, suggesting that the type of $P$ fertilization did not significantly affect the $\mathrm{P}_{\mathrm{o}}$ speciation in the soil. This is in line with previous studies on long-term fertilization trials $[4,19,32,56]$ and implies that at all three sites, differences in $P_{o}$ speciation were mainly controlled by site-specific factors, such as soil properties or soil management practice. However, most of the above-mentioned studies were restricted to $P_{o}$ speciation of the topsoil. Results from this study indicated that the effect of treatment in the subsoil was not consistent over all sites, e.g., accumulation of monoesters in the Bad Lauchstädt subsoil. This confirmed that P in Bad Lauchstädt is more prone to downward movement because of the soil properties, but other factors, including trial duration, application levels, initial P sorption capacity, and DPS may also play a role here.

The proportion of $\mathrm{P}_{\mathrm{o}}$ detected by $\mathrm{P}$ XANES correlated significantly with the proportions of $\mathrm{P}_{\mathrm{O}}$ on total $\mathrm{P}$ extracted with $\mathrm{NaOH}$-EDTA $\left(R^{2}=0.73, P<0.001\right)$ and extractable $\mathrm{P}_{\mathrm{o}}$ quantified by ${ }^{31} \mathrm{P}$ NMR $\left(R^{2}=0.53\right.$, $P<0.001)$. This confirms a reasonable comparability of both methods despite the known limitation of $P$ $K$-edge XANES in identifying $\mathrm{P}_{\mathrm{o}}$ in complex matrices like soils [33]. In agreement with sequential fractionation $\left(\mathrm{H}_{2} \mathrm{SO}_{4}-\mathrm{P}\right)$, Ca-P substantially contributed to $\mathrm{P}$ speciation at all three sites. In Bad Lauchstädt, $\mathrm{P}$ associated with $\mathrm{Ca}$ increased with depth up to $56 \%$ (Table 2). This was in line with the highest $\mathrm{H}_{2} \mathrm{SO}_{4}-\mathrm{P}$ stocks among all studied sites comprising of relatively stable $\mathrm{P}$ most likely associated with $\mathrm{Ca}$ and $\mathrm{Mg}$ minerals $[15,23,50]$ and reflected the calcareous parent material of the Haplic 
Chernozem in Bad Lauchstädt [3]. Similarly, the majority of Ca-associated P being found in $60-90 \mathrm{~cm}$ subsoil of the control can be attributed to the presence of primary $\mathrm{P}$ minerals in the calcareous material in the deeper subsoil. The higher proportions of $\mathrm{Ca}-\mathrm{P}$ in the unfertilized topsoil at Freising Dürnast and Dahlem compared to the underlying subsoil layer $(30-60 \mathrm{~cm})$ are most likely a result of the continuous lime application and accumulation of $\mathrm{Ca}-\mathrm{P}$ in this otherwise rather decalcified part of the soil profile.

Treatment effects on $\mathrm{P}$ speciation were again inconsistent among sites. Combined mineral + organic P fertilization resulted in almost no difference in $\mathrm{P}$ speciation in Freising Dürnast, which was in agreement with ${ }^{31} \mathrm{P}$ NMR. This was likely due to the relatively short duration of the trial, with changes too small to be detected by P XANES spectroscopy. The increasing proportions of $\mathrm{Al}-\mathrm{P}$ in the topsoils at the expense of $\mathrm{Fe}-\mathrm{P}$ after the application of fertilizer in Dahlem and Bad Lauchstädt confirmed results from other scientists showing that mineral fertilizer $\mathrm{P}$ was first associated with $\mathrm{Al}$ compounds in the topsoil $[20,21]$. The fact that proportions of Al-P in the subsoils with or without fertilization showed no great difference suggests that the leached fertilizer P most likely accumulated in other P forms in the subsoil. The P forms were also determined by site-specific properties. For instance, at Dahlem, leached $\mathrm{P}$ accumulated in the upper subsoil layer in the form of $\mathrm{Ca}-\mathrm{P}$ as a result of continuous liming and the high content of $\mathrm{Ca}-\mathrm{P}$ in organic farmyard manures [22]. The accumulation of $P_{o}$ in the $30-50 \mathrm{~cm}$ subsoil layer was in agreement with the ${ }^{31} \mathrm{P}$ NMR results and can be attributed to an enhanced downward transport of fertilizer $\mathrm{P}$ due to the low $\mathrm{P}$ sorption capacities and high DPS (Additional file 1: Fig. S1) of the sandy and clay-depleted horizons above the argic horizon starting at soil depths of around $65 \mathrm{~cm}$. By contrast, the observed increase in $\mathrm{P}_{\mathrm{o}}$, especially in the $60-90 \mathrm{~cm}$ subsoil layer, suggests that the risk of $\mathrm{P}_{\mathrm{o}}$ leaching seams higher in $\mathrm{Bad}$ Lauchstädt compared to Dahlem. This is likely due to the less restricted downward P transport within the porerich chernic horizon and the higher past and current organic P application rates.

\section{Relation of $\mathrm{P}_{\mathrm{DGT}}$ to other soil $\mathrm{P}$ tests and consequences for crop response prediction}

When looking at the linear correlations of extracted soil $\mathrm{P}$ with $\mathrm{P}_{\mathrm{DGT}}$, it is apparent that to some extent, all methods access a similar soil $\mathrm{P}$ pool commonly known as plant-available $\mathrm{P}[18,54]$. Thus, the increase in labile $\mathrm{P}$ after fertilization, especially after the addition of mineral fertilizer, which was in agreement with other studies [7, $22,32]$, was not only reflected in sequentially extracted $P$ pools, but also in $\mathrm{P}_{\mathrm{CAL}}, \mathrm{P}_{\mathrm{DL}}$, and $\mathrm{P}_{\mathrm{DGT}}$ (Additional file 1: Table S5; Fig. 2).

The $\mathrm{P}_{\mathrm{DGT}}$ concentration can be viewed as the highly labile fraction of $\mathrm{P}_{\mathrm{CAL}}$ or $\mathrm{P}_{\mathrm{DL}}$ (Fig. 3), which is replenished over time within the $\mathrm{P}_{\mathrm{CAL}}$ or $\mathrm{P}_{\mathrm{DL}}$ pool. Correlations were generally comparable or better for the $\mathrm{P}_{\mathrm{CAL}}$ than for $\mathrm{P}_{\mathrm{DL}}$, which is likely a result of the soil $\mathrm{pH}$. In general, CAL should be applied for soils exhibiting a $\mathrm{pH}>6$, while $\mathrm{DL}$ is used for soils with a $\mathrm{pH}<6$ to also include apatitic phosphate in acidic soils [57]. As the $\mathrm{pH}$ of most samples was $>6$, CAL performed better in extracting the labile $\mathrm{P}$ pool and thus correlated better to $\mathrm{P}_{\mathrm{DGT}}$. Higher coefficients of determination found for correlations between $\mathrm{P}_{\text {CAL }}$ and $\mathrm{P}_{\mathrm{DGT}}$ when also incorporating the subsoils is most probably due to slightly higher $\mathrm{pH}$ values in subsoils compared to the topsoil. However, although correlations were highly significant, the $R^{2}$ is only between 0.27 and 0.60 , suggesting that the results of these methods cannot be fully transferred to each other by simple regressions, as was the case in this study. Therefore, further research on a much larger and more diverse sample set is needed to test the usability of additional soil parameters in multiple regressions so as to further improve predictability and, more generally, the usability of such transfer functions.

We also determine the ability of the different soil $\mathrm{P}$ tests to model crop yield response using the Mitscherlich equation. The highest $R^{2}$ were obtained using the $\mathrm{P}_{\mathrm{DGT}}$ data, which is in accordance with literature claiming that DGT accurately determines yield response to $\mathrm{P}$ fertilization in pot experiments [74] and field trials [40, 41, 45, $47,59,60,62]$. Up till now, most studies that related $\mathrm{P}$ predictions to yield based on $\mathrm{P}_{\mathrm{DGT}}$ were performed on Australian or tropical topsoils and only one study examined agriculturally used soils in Europe [47]. However, within this extensive study, only the topsoils of eleven different experimental fields were considered and there was no focus on subsoils. To evaluate the subsoils for crop production in agriculturally used soil in Europe, crop prediction models should also include subsoil layers, with this study representing a first step to closing this gap.

The coefficients of determination for the regression fit $R^{2}$ predicting yield response to soil $\mathrm{P}$ of different soil $\mathrm{P}$ tests were consistently better in topsoil than when incorporating one or all subsoil layers (Fig. 4). This implies that the majority of $\mathrm{P}$ taken up by plants originates from the topsoil. However, since the inclusion of subsoil layers only resulted in a significant prediction of yield response for $\mathrm{P}_{\mathrm{DGT}}$ - even when gradually decreasing with depththis suggests that the plant at least partially absorbed $\mathrm{P}_{\mathrm{DGT}}$ from the subsoil. It is known that plans can also acquire $P$ from the subsoil $[7,29]$, but to what extent and under which possible plant-specific conditions remain 
unclear. It is believed that P deficiencies in the topsoil can stimulate P acquisition from the subsoil [29], but at the same time, only a sufficient overall nutrient status in the topsoil leads to a high plant $\mathrm{P}$ uptake, facilitating root growth and, in turn, the acquisition of $P$ from the subsoil. For instance, [7] was able to show that under N-limiting conditions, the utilization of subsoil $\mathrm{P}$ resources was restricted.

\section{Conclusion}

In summary, the literature and our own results have shown that plants are also capable of mobilizing $\mathrm{P}$ from deeper soil layers when there is a negative $\mathrm{P}$ budget in the topsoil [24, 32, 79]. The results of this study represent a good basis for future calculations on the influence of different subsoil layers for P plant uptake, as we provide the initial values of the stocks down to $90 \mathrm{~cm}$ for four test sites. We conclude that not only the topsoil but also deeper soil layers, the duration of the experiment, and soil properties have to be considered to guarantee a balanced P budget and reduce the risks of P leaching. Although the leaching of fertilizer P down the complete soil profile $(0-90 \mathrm{~cm})$ was observed for some sites, the influence of different $\mathrm{P}$ fertilizers on $\mathrm{P}$ pools and speciation was not very strong and mostly management- and site-specific, as well as being most pronounced in the topsoil. The topsoil also mainly contributed to the plant $\mathrm{P}$ uptake, as reflected in the Mitscherlich fits.

Although subsoil stocks were larger (among all subsoil layers) and the available P stocks of the subsoil were comparable or slightly lower than the available P stocks of the topsoil, there was no need for the plant to acquire substantial amounts of subsoil $\mathrm{P}$ due to the good $\mathrm{P}$ supply of the topsoil. For example, even after almost 100 years without P fertilization in Dahlem, there was only around a $10 \%$ yield decrease of wheat in the control treatment, but no significant reduction in the labile $P$ stocks of the subsoils. This also indicates that the accessibility for plants is lower, despite the subsoil volume that can potentially be rooted by plants being many times higher than the topsoil volume. It can therefore be deduced that $P$ fertilization tends to fill up the P reservoirs of the subsoil-the extent to which is dependent on site properties and management history-rather than largely contributing to plant nutrition in soils with good P status. A generalization of fertilization effects over different sites is rather difficult, as they largely depend on soil properties and fertilization management. However, we were able to show that, depending on the type of organic P fertilizer, the proportion of labile $\mathrm{P}$ was affected differently, with farmyard manure $\mathrm{P}$ exhibiting higher plant availability than green manure or compost. Among the tested soil P tests, the DGT method was best at predicting the plant response to $\mathrm{P}$ application, regardless of soil properties and crop type. Thus, we conclude that the DGT method is a mechanistic surrogate of $P$ plant uptake and superior to equilibrium-type chemical extraction procedures at estimating potential crop yields, as it is independent of factors like soil type or soil $\mathrm{pH}$.

\begin{abstract}
Abbreviations
Alox: ammonium oxalate extractable Al; ACP: Amorphous calcium phosphate; CAL: Calcium-acetate lactate; CLS: Canadian Light Source; DL: Double-lactate; DGT: Diffusive gradients in thin films; $\mathrm{D}_{2} \mathrm{O}$ : Deuterated water; DPS: Degree of P saturation; $\mathrm{DL}$ : Double-lactate; $\mathrm{Fe}_{\mathrm{ox}}$ : ammonium oxalate extractable $\mathrm{Fe}$; FYM: Farmyard manure; ICP-OES: Inductively coupled plasma-optical emission spectroscopy; $P_{i}$ : Inorganic P; LCF: Linear combination fitting; MDPA: Methylendioxypropylamphetamine; NMR: Nuclear magnetic resonance; $P_{\mathrm{o}}$ : Organic $P$; SXRMB: Soft X-ray Microcharacterization Beamline; $P_{\text {tot }}$ :Total $P$; $P_{\text {ox }}$ : ammonium oxalate extractable $P$; XANES: $X$-ray absorption near edge structure.
\end{abstract}

\section{Supplementary Information}

The online version contains supplementary material available at https://doi. org/10.1186/s12302-021-00496-w.

Additional file 1. Results on 'General soil parameters' and discussion on 'Influence of fertilization on C and N stocks'. Table S1. Details about long-term experimental fields. Table S2. Total P stocks and P budgets. Table S3. General soil characteristics. Table S4. Sequential P fractionation data. Table S5. $P_{D L}$ and $P_{C A L}$ stocks. Table S6. Crop yields. Table S7. Mitscherlich fitting parameters. Figure S1. DPS for long-term experimental sites. Figure S2 and Figure S3. NMR spectra of NMR spiking experiment. Figure S4 to Figure S9. NMR spectra of the soil samples. Figure S10. P K-edge XANES spectra of the soil samples.

\section{Acknowledgements}

The authors would like to thank M. Koch for the help in taking soil samples in Dahlem and Bad Lauchstädt. In addition, we thank M. Koch and H. Zeymer for his support in the lab. The P K-edge XANES research described in this paper was performed at the Canadian Light Source (CLS), which is supported by the Canadian Foundation for Innovation, Natural Sciences and Engineering Research Council of Canada, the University of Saskatchewan, the Government of Saskatchewan, Western Economic Diversification Canada, the National Research Council Canada, and the Canadian Institutes of Health Research. The authors would like to thank one of the best beamline scientist team, i.e., Yongfeng Hu, Qunfeng Xiao, and Aimee Maclennan at CLS for technical support. We would also like to thank P. Narf.

\section{Authors' contributions}

NS raised the funds for this project. JK, and TF conducted sequential P fractionation and data interpretation. NS conducted DGT analyses and data interpretation. LW conducted NMR analyses, and LW and JK performed NMR data interpretation. JK conducted XANES analyses, and JK and NS performed XANES data interpretation. SVT, IM, and KS supervised the long-term experiments, provided sample material, and helped with the interpretation of the data. NS and JK were the major contributors in writing the manuscript. All authors read and approved the final manuscript.

\section{Funding}

Open Access funding enabled and organized by Projekt DEAL. The authors would like to thank the German Federal Ministry of Education and Research (BMBF) for funding the BonaRes project InnoSoilPhos [Grant Number 031A558].

\section{Availability of data and materials}

The datasets used and/or analysed during the current study are available from the corresponding author on reasonable request. 


\section{Declarations}

Ethics approval and consent to participate

Not applicable.

\section{Consent for publication}

Not applicable.

\section{Competing interests}

The authors declare that they have no competing interests.

\section{Author details}

${ }^{1}$ Institute of Bio- and Geosciences-Agrosphere (IBG-3), Forschungszentrum Jülich, 52425 Jülich, Germany. ${ }^{2}$ Crop Physiology, Technical University of Munich, Alte Akademie 12, 85350 Freising-Weihenstephan, Germany. ${ }^{3}$ Bad Lauchstädt Experimental Station, Helmholtz Centre for Environmenta Research-UFZ, Leipzig-Halle, Hallesche Str. 44, 06246 Bad Lauchstädt, Germany. ${ }^{4}$ Thaer-Institute of Agricultural and Horticultural Sciences, HumboldtUniversität zu Berlin, Albrecht-Thaer-Weg 5, 14195 Berlin, Germany. ${ }^{5}$ Institute of Crop Science and Resource Conservation (INRES), Soil Science and Soil Ecology, University of Bonn, Nussallee 13, 53115 Bonn, Germany.

Received: 15 December 2020 Accepted: 15 April 2021

Published online: 17 May 2021

\section{References}

1. Ahlgren J, Djodjic F, Börjesson G, Mattsson L (2013) Identification and quantification of organic phosphorus forms in soils from fertility experiments. Soil Use Manag 29:24-35. https://doi.org/10.1111/sum.12014

2. Ahmed AA, Gypser S, Leinweber P, Freese D, Kühn O (2019) Infrared spectroscopic characterization of phosphate binding at the goethite-water interface. Phys Chem Chem Phys 21:4421-4434. https://doi.org/10.1039/ C8CP07168C

3. Altermann M, Rinklebe J, Merbach I, Körschens M, Langer U, Hofmann B (2005) Chernozem-soil of the year 2005. J Plant Nutr Soil Sci 168:725740. https://doi.org/10.1002/jpln.200521814

4. Annaheim KE, Doolette AL, Smernik RJ, Mayer J, Oberson A, Frossard E, Bünemann EK (2015) Long-term addition of organic fertilizers has little effect on soil organic phosphorus as characterized by 31P NMR spectroscopy and enzyme additions. Geoderma 257-258:67-77. https:// doi.org/10.1016/j.geoderma.2015.01.014 (Special issue on developments in soil organic phosphorus cycling in natural and agricultural ecosystems)

5. Audette Y, O'Halloran IP, Paul Voroney R (2016) Kinetics of phosphorus forms applied as inorganic and organic amendments to a calcareous soil. Geoderma 262:119-124. https://doi.org/10.1016/j.geoderma.2015.08.021

6. Barej JAM, Pätzold S, Perkons U, Amelung W (2014) Phosphorus fractions in bulk subsoil and its biopore systems. Eur J Soil Sci 65:553-561. https:// doi.org/10.1111/ejss.12124

7. Bauke SL, von Sperber C, Tamburini F, Gocke MI, Honermeier B, Schweitzer K, Baumecker M, Don A, Sandhage-Hofmann A, Amelung W (2018) Subsoil phosphorus is affected by fertilization regime in long-term agricultural experimental trials. Eur J Soil Sci 69:103-112. https://doi.org/ 10.1111/ejss.12516

8. Baveye PC (2015) Looming scarcity of phosphate rock and intensification of soil phosphorus research. Rev Bras Ciênc Solo 39:637-642. https://doi. org/10.1590/01000683rbcs20140819

9. Beauchemin S, Hesterberg D, Chou J, Beauchemin M, Simard RR, Sayers DE (2003) Speciation of phosphorus in phosphorus-enriched agricultural soils using X-ray absorption near-edge structure spectroscopy and chemical fractionation. J Environ Qual 32:1809-1819. https://doi.org/10. 2134/jeq2003.1809

10. Cade-Menun B, Liu CW (2014) Solution phosphorus-31 nuclear magnetic resonance spectroscopy of soils from 2005 to 2013: a review of sample preparation and experimental parameters. Soil Sci Soc Am J 78:19-37. https://doi.org/10.2136/sssaj2013.05.0187dgs
11. Cade-Menun BJ (2017) Characterizing phosphorus forms in cropland soils with solution 31P-NMR: past studies and future research needs. Chem Biol Technol Agric 4:19. https://doi.org/10.1186/s40538-017-0098-4

12. Cade-Menun BJ (2005) Characterizing phosphorus in environmental and agricultural samples by 31P nuclear magnetic resonance spectroscopy. Talanta 66:359-371. https://doi.org/10.1016/j.talanta.2004.12.024

13. Cade-Menun BJ, Elkin KR, Liu CW, Bryant RB, Kleinman PJA, Moore PA (2018) Characterizing the phosphorus forms extracted from soil by the Mehlich III soil test. Geochem Trans 19:7. https://doi.org/10.1186/ s12932-018-0052-9

14. Calvin S (2013) XAFS for everyone. CRC Press, Boca Raton. https://doi.org/ $10.1201 /$ b14843

15. Chang SC, Jackson ML (1957) Fractionation of soil phosphorus. Soil Sci 84:133-144

16. Condron LM, Frossard E, Tiessen H, Newmans RH, Stewart JWB (1990) Chemical nature of organic phosphorus in cultivated and uncultivated soils under different environmental conditions. J Soil Sci 41:41-50. https://doi.org/10.1111/j.1365-2389.1990.tb00043.x

17. Cross AF, Schlesinger WH (1995) A literature review and evaluation of the. Hedley fractionation: applications to the biogeochemical cycle of soil phosphorus in natural ecosystems. Geoderma 64:197-214. https://doi. org/10.1016/0016-7061(94)00023-4

18. Degryse F, Smolders E, Zhang H, Davison W (2009) Predicting availability of mineral elements to plants with the DGT technique: a review of experimental data and interpretation by modelling. Environ Chem 6:198-218. https://doi.org/10.1071/EN09010

19. Dou Z, Ramberg CF, Toth JD, Wang Y, Sharpley AN, Boyd SE, Chen CR, Williams D, Xu ZH (2009) Phosphorus speciation and sorption-desorption characteristics in heavily manured soils. Soil Sci Soc Am J 73:93-101. https://doi.org/10.2136/sssaj2007.0416

20. Eriksson AK, Gustafsson JP, Hesterberg D (2015) Phosphorus speciation of clay fractions from long-term fertility experiments in Sweden. Geoderma 241-242:68-74. https://doi.org/10.1016/j.geoderma.2014.10.023

21. Eriksson AK, Hesterberg D, Klysubun W, Gustafsson JP (2016) Phosphorus dynamics in Swedish agricultural soils as influenced by fertilization and mineralogical properties: insights gained from batch experiments and XANES spectroscopy. Sci Total Environ 566-567:1410-1419. https://doi. org/10.1016/j.scitotenv.2016.05.225

22. Glæsner N, van der Bom F, Bruun S, McLaren T, Larsen FH, Magid J (2019) Phosphorus characterization and plant availability in soil profiles after long-term urban waste application. Geoderma 338:136-144. https://doi. org/10.1016/j.geoderma.2018.11.046

23. Golterman HL, Booman A (1988) Sequential extraction of iron-phosphate and calcium-phosphate from sediments by chelating agents. SIL Proc 1922-2010(23):904-909. https://doi.org/10.1080/03680770.1987.11899 738

24. Gransee A, Merbach W (2000) Phosphorus dynamics in a long-term P fertilization trial on Luvic Phaeozem at Halle. J Plant Nutr Soil Sci 163:353-357. https://doi.org/10.1002/1522-2624(200008)163:4\%3c353:: AID-JPLN353\%3e3.0.CO;2-B

25. Gypser S, Hirsch F, Schleicher AM, Freese D (2018) Impact of crystalline and amorphous iron- and aluminum hydroxides on mechanisms of phosphate adsorption and desorption. J Environ Sci 70:175-189. https://doi. org/10.1016/j.jes.2017.12.001

26. Heckenmüller M, Narita D, Klepper G (2014) Global availability of phosphorus and its implications for global food supply: an economic overview (Working Paper No. 1897). Kiel Working Paper

27. Hedley MJ, Stewart JWB, Chauhan BS (1982) Changes in inorganic and organic soil phosphorus fractions induced by cultivation practices and by laboratory incubations. Soil Sci Soc Am J 46:970-976. https://doi.org/10. 2136/sssaj1982.03615995004600050017x

28. Jensen M, Bjørn Olsen T, Bruun Hansen HC, Magid J (2000) Dissolved and particulate phosphorus in leachate from structured soil amended with fresh cattle faeces. Nutr Cycl Agroecosyst 56:253-261. https://doi.org/10. 1023/A:1009837520420

29. Kautz T, Amelung W, Ewert F, Gaiser T, Horn R, Jahn R, Javaux M, Kemna A, Kuzyakov Y, Munch J-C, Pätzold S, Peth S, Scherer HW, Schloter M, Schneider H, Vanderborght J, Vetterlein D, Walter A, Wiesenberg GLB, Köpke U (2013) Nutrient acquisition from arable subsoils in temperate climates: a review. Soil Biol Biochem 57:1003-1022. https://doi.org/10.1016/j.soilbio. 2012.09.014 
30. Knapp AK, Smith MD, Hobbie SE, Collins SL, Fahey TJ, Hansen GJA, Landis DA, La Pierre KJ, Melillo JM, Seastedt TR, Shaver GR, Webster JR (2012) Past, present, and future roles of long-term experiments in the LTER network. Bioscience 62:377-389. https://doi.org/10.1525/bio.2012.62.4.9

31. Koch M, Guppy C, Amelung W, Gypser S, Bol R, Seidel S, Siebers N (2019) Insights into 33phosphorus utilisation from Fe- and Al-hydroxides in Luvisol and Ferralsol subsoils. Soil Res 57:447. https://doi.org/10.1071/ SR18223

32. Koch M, Kruse J, Eichler-Löbermann B, Zimmer D, Willbold S, Leinweber P, Siebers N (2018) Phosphorus stocks and speciation in soil profiles of a long-term fertilizer experiment: evidence from sequential fractionation, P K-edge XANES, and 31 P NMR spectroscopy. Geoderma 316:115-126. https://doi.org/10.1016/j.geoderma.2017.12.003

33. Kruse J, Abraham M, Amelung W, Baum C, Bol R, Kühn O, Lewandowski H, Niederberger J, Oelmann Y, Rüger C, Santner J, Siebers M, Siebers N, Spohn M, Vestergren J, Vogts A, Leinweber P (2015) Innovative methods in soil phosphorus research: a review. J Plant Nutr Soil Sci 178:43-88. https://doi.org/10.1002/jpln.201400327

34. Kruse J, Koch M, Khoi CM, Braun G, Sebesvari Z, Amelung W (2020) Land use change from permanent rice to alternating rice-shrimp or permanent shrimp in the coastal Mekong Delta, Vietnam: changes in the nutrient status and binding forms. Sci Total Environ 703:134758. https:// doi.org/10.1016/j.scitotenv.2019.134758

35. Kuhlmann H, Baumgärtel G (1991) Potential importance of the subsoil for the $P$ and Mg nutrition of wheat. Plant Soil 137:259-266. https://doi.org/ 10.1007/BF00011204

36. Lei L, YiBing M, Sanders RL, Chuang X, JuMei L, Myneni SCB (2017) Phosphorus speciation and transformation in long-term fertilized soil: evidence from chemical fractionation and P K-edge XANES spectroscopy. Nutr Cycl Agroecosyst 107:215-226

37. Leinweber P, Haumaier L, Zech W (1997) Sequential extractions and 31P-NMR spectroscopy of phosphorus forms in animal manures, whole soils and particle-size separates from a densely populated livestock area in northwest Germany. Biol Fertil Soils 25:89-94. https://doi.org/10.1007/ s003740050286

38. Liu E, Yan C, Mei X, Zhang Y, Fan T (2013) Long-term effect of manure and fertilizer on soil organic carbon pools in dryland farming in northwest China. PLoS ONE. https://doi.org/10.1371/journal.pone.0056536

39. Magid J, Luxhøi J, Jensen LS, Møller J, Bruun S (2006) Establishment of a long-term field trial with urban fertilizers - is recycling of nutrients from urban areas to peri-urban organic farms feasible? In: Raupp J, Pekrun C, Oltmanns M, Köpke U (eds) Long-term field experiments in organic farming. Stollfuß Medien, Berlin, Scientific Series / ISOFAR, pp 59-78

40. Mason S, Hamon R, Zhang H, Anderson J (2008) Investigating chemical constraints to the measurement of phosphorus in soils using diffusive gradients in thin films (DGT) and resin methods. Talanta 74:779-787. https://doi.org/10.1016/.t.talanta.2007.07.005

41. Mason S, McNeill A, McLaughlin MJ, Zhang H (2010) Prediction of wheat response to an application of phosphorus under field conditions using diffusive gradients in thin-films (DGT) and extraction methods. Plant Soil 337:243-258. https://doi.org/10.1007/s11104-010-0521-0

42. McDowell RW, Stewart I, Cade-Menun BJ (2006) An examination of spin-lattice relaxation times for analysis of soil and manure extracts by liquid state phosphorus-31 nuclear magnetic resonance spectroscopy. J Environ Qual 35:293-302. https://doi.org/10.2134/jeq2005.0285

43. MCLaren TI, Smernik RJ, Guppy CN, Bell MJ, Tighe MK (2014) The organic p composition of vertisols as determined by 31P NMR spectroscopy. Soil Sci Soc Am J 78:1893-1902. https://doi.org/10.2136/sssaj2014.04.0139

44. Medinski T, Freese D, Reitz T (2018) Changes in soil phosphorus balance and phosphorus-use efficiency under long-term fertilization conducted on agriculturally used Chernozem in Germany. Can J Soil Sci 98:650-662. https://doi.org/10.1139/cjss-2018-0061

45. Menzies NW, Kusumo B, Moody PW (2005) Assessment of P availability in heavily fertilized soils using the diffusive gradient in thin films (DGT) technique. Plant Soil 269:1-9. https://doi.org/10.1007/s11104-004-1725-y

46. Murphy J, Riley JP (1962) A modified single solution method for the determination of phosphate in natural waters. Anal Chim Acta 27:31-36. https://doi.org/10.1016/50003-2670(00)88444-5

47. Nawara S, Dael TV, Merckx R, Amery F, Elsen A, Odeurs W, Vandendriessche H, Mcgrath S, Roisin C, Jouany C, Pellerin S, Denoroy P, EichlerLöbermann B, Börjesson G, Goos P, Akkermans W, Smolders E (2017)
A comparison of soil tests for available phosphorus in long-term field experiments in Europe. Eur J Soil Sci 68:873-885. https://doi.org/10.1111/ ejss. 12486

48. Pautler M, Sims J (2000) Relationships between soil test phosphorus, soluble phosphorus, and phosphorus saturation in Delaware soils. Soil Sci Soc Am J. https://doi.org/10.2136/sssaj2000.642765x

49. Penn CJ, Camberato JJ (2019) A critical review on soil chemical processes that control how soil pH affects phosphorus availability to plants. Agriculture 9:120. https://doi.org/10.3390/agriculture9060120

50. Pierzynski GM, McDowell RW, Sims JT (2015) Chemistry, cycling, and potential movement of inorganic phosphorus in soils. Phosphorus: agriculture and the environment. Wiley, pp 51-86 https://doi.org/10.2134/ agronmonogr46.c3

51. Ravel B, Newville M (2005) ATHENA, ARTEMIS, HEPHAESTUS: data analysis for X-ray absorption spectroscopy using IFEFFIT. J Synchrotron Radiat 12:537-541. https://doi.org/10.1107/S0909049505012719

52. Reddy DD, Rao SA, Singh M (2005) Changes in P fractions and sorption in an Alfisol following crop residues application. J Plant Nutr Soil Sci 168:241-247. https://doi.org/10.1002/jpln.200421444

53. Riehm H (1938) Die Bestimmung der laktatlöslichen Phosphorsäure im Boden unter Verwendung eines lichtelektrischen Kolorimeters. Bodenkd Pflanzenernähr 9:30-50. https://doi.org/10.1002/jpln.19380090107

54. Schick J, Kratz S, Rückamp D, Shwiekh R, Haneklaus S, Schnug E (2013) Comparison and inter-calibration of different soil P tests used in the Baltic Sea Countries, knowledge report: Baltic manure business opportunities

55. Schmieder F, Bergström L, Riddle M, Gustafsson J-P, Klysubun W, Zehetner F, Condron L, Kirchmann H (2018) Phosphorus speciation in a long-term manure-amended soil profile-evidence from wet chemical extraction, 31P-NMR and P K-edge XANES spectroscopy. Geoderma 322:19-27. https://doi.org/10.1016/j.geoderma.2018.01.026

56. Schneider KD, Cade-Menun BJ, Lynch DH, Voroney RP (2016) Soil phosphorus forms from organic and conventional forage fields. Soil Sci Soc Am J 80:328-340. https://doi.org/10.2136/sssaj2015.09.0340

57. Schüller H (1969) Die CAL-Methode, eine neue Methode zur Bestimmung des pflanzenverfügbaren phosphates in Böden. Z Für Pflanzenernähr Bodenkd 123:48-63. https://doi.org/10.1002/jpln.19691230106

58. Schwertmann U (1964) Differenzierung der Eisenoxide des Bodens durch Extraktion mit Ammoniumoxalat-Lösung. Z Für Pflanzenernähr Düng Bodenkd 105:194-202. https://doi.org/10.1002/jpln.3591050303

59. Six L, Pypers P, Degryse F, Smolders E, Merckx R (2012) The performance of DGT versus conventional soil phosphorus tests in tropical soils - an isotope dilution study. Plant Soil 359:267-279. https://doi.org/10.1007/ S11104-012-1192-9

60. Six L, Smolders E, Merckx R (2014) Testing phosphorus availability for maize with DGT in weathered soils amended with organic materials. Plant Soil 376:177-192. https://doi.org/10.1007/s11104-013-1947-y

61. Smith VH, Schindler DW (2009) Eutrophication science: where do we go from here? Trends Ecol Evol 24:201-207. https://doi.org/10.1016/j.tree. 2008.11.009

62. Speirs SD, Scott BJ, Moody PW, Mason SD (2013) Soil phosphorus tests Il: a comparison of soil test-crop response relationships for different soil tests and wheat. Crop Pasture Sci 64:469-479. https://doi.org/10.1071/ CP13111

63. Stutter MI, Shand CA, George TS, Blackwell MSA, Dixon L, Bol R, MacKay RL, Richardson AE, Condron LM, Haygarth PM (2015) Land use and soil factors affecting accumulation of phosphorus species in temperate soils. Geoderma 257-258:29-39. https://doi.org/10.1016/j.geoderma.2015. 03.020 (Special issue on developments in soil organic phosphorus cycling in natural and agricultural ecosystems)

64. Syers JK, Johnston AE, Curtin D (2008) Efficiency of soil and fertilizer phosphorus use. Reconciling changing concepts of soil phosphorus behaviour with agronomic information. FAO Fertil Plant Nutr Bull. FAO

65. Tandy S, Mundus S, Yngvesson J, de Bang TC, Lombi E, Schjoerring JK, Husted S (2011) The use of DGT for prediction of plant available copper, zinc and phosphorus in agricultural soils. Plant Soil 346:167-180. https:// doi.org/10.1007/s11104-011-0806-y

66. Turner BL (2008) Soil organic phosphorus in tropical forests: an assessment of the $\mathrm{NaOH}-\mathrm{EDTA}$ extraction procedure for quantitative analysis by solution 31P NMR spectroscopy. Eur J Soil Sci 59:453-466. https://doi. org/10.1111/j.1365-2389.2007.00994.x 
67. Turner BL, Cade-Menun BJ, Condron LM, Newman S (2005) Extraction of soil organic phosphorus. Talanta 66:294-306. https://doi.org/10.1016/j. talanta.2004.11.012 (Analysis of Phosphorus in Environmental and Agricultural Samples)

68. Turner BL, Cheesman AW, Godage HY, Riley AM, Potter BVL (2012) Determination of neo- and D-chiro-Inositol Hexakisphosphate in soils by solution 31P NMR spectroscopy. Environ Sci Technol 46:4994-5002. https:// doi.org/10.1021/es204446z

69. Turner BL, Richardson AE (2004) Identification of scyllo-inositol phosphates in soil by solution phosphorus-31 nuclear magnetic resonance spectroscopy. Soil Sci Soc Am J 68:802-808. https://doi.org/10.2136/sssaj 2004.8020

70. van der Bom FJT, McLaren TI, Doolette AL, Magid J, Frossard E, Oberson A, Jensen LS (2019) Influence of long-term phosphorus fertilisation history on the availability and chemical nature of soil phosphorus. Geoderma 355:113909. https://doi.org/10.1016/j.geoderma.2019.113909

71. VDLUFA (1991) Methode A 6.2.1.2, Bestimmung von Phosphor und Kalium im Doppellactat (DL)-Auszug. In: Handbuch der Landwirtschaftlichen Versuchs- und Untersuchungs methodik (VDLUFA-Methodenbuch), Bd. I Die Untersuchung von Böden, 4. Auflage, VDLUFA-Verlag, Darmstadt

72. VDLUFA (2012) Methode A 6.2.1.1, Bestimmung von Phosphor und Kalium im Calcium-Acetat-Lactat-Auszug. In: Handbuch der Landwirtschaftlichen Versuchs- und Untersuchungsmethodik (VDLUFA-Methodenbuch), Bd. I Die Untersuchung von Böden, 4. Auflage, 6. Teillieferung, VDLUFA-Verlag, Darmstadt

73. Velásquez G, Ngo P-T, Rumpel C, Calabi-Floody M, Redel Y, Turner BL, Condron LM, de la Luz Mora M (2016) Chemical nature of residual phosphorus in andisols. Geoderma 271:27-31. https://doi.org/10.1016/j.geode rma.2016.01.027
74. Vogel C, Sekine R, Steckenmesser D, Lombi E, Steffens D, Adam C (2017) Phosphorus availability of sewage sludge-based fertilizers determined by the diffusive gradients in thin films (DGT) technique. J Plant Nutr Soil Sci 180:594-601. https://doi.org/10.1002/jpln.201600531

75. Wechsung G, Pagel H (1993) Akkumulation und Mobilisation von Phosphaten in einer Schwarzerde im Statischen Dauerversuch Lauchstädt - Betrachtung der P-Bilanz nach 84 Versuchsjahren. Z Für Pflanzenernähr Bodenkd 156:301-306. https://doi.org/10.1002/jpln.19931560405

76. Wei K, Bao H, Huang S, Chen L (2017) Effects of long-term fertilization on available $\mathrm{P}, \mathrm{P}$ composition and phosphatase activities in soil from the Huang-Huai-Hai Plain of China. Agric Ecosyst Environ 237:134-142. https://doi.org/10.1016/j.agee.2016.12.030

77. Wuenscher R, Unterfrauner H, Peticzka R, Zehetner F (2015) A comparison of 14 soil phosphorus extraction methods applied to 50 agricultural soils from Central Europe. Plant Soil Environ 61:86-96. https://doi.org/10. 17221/932/2014-PSE

78. Zhang H, Davison W, Gadi R, Kobayashi T (1998) In situ measurement of dissolved phosphorus in natural waters using DGT. Anal Chim Acta 370:29-38. https://doi.org/10.1016/S0003-2670(98)00250-5

79. Zicker T, von Tucher S, Kavka M, Eichler-Löbermann B (2018) Soil test phosphorus as affected by phosphorus budgets in two long-term field experiments in Germany. Field Crops Res 218:158-170. https://doi.org/10. 1016/j.fcr.2018.01.008

\section{Publisher's Note}

Springer Nature remains neutral with regard to jurisdictional claims in published maps and institutional affiliations.

\section{Submit your manuscript to a SpringerOpen ${ }^{\circ}$ journal and benefit from:}

- Convenient online submission

- Rigorous peer review

- Open access: articles freely available online

- High visibility within the field

- Retaining the copyright to your article

Submit your next manuscript at $\boldsymbol{\nabla}$ springeropen.com 